rudolf p. botha

the world of language

4 its codelike core
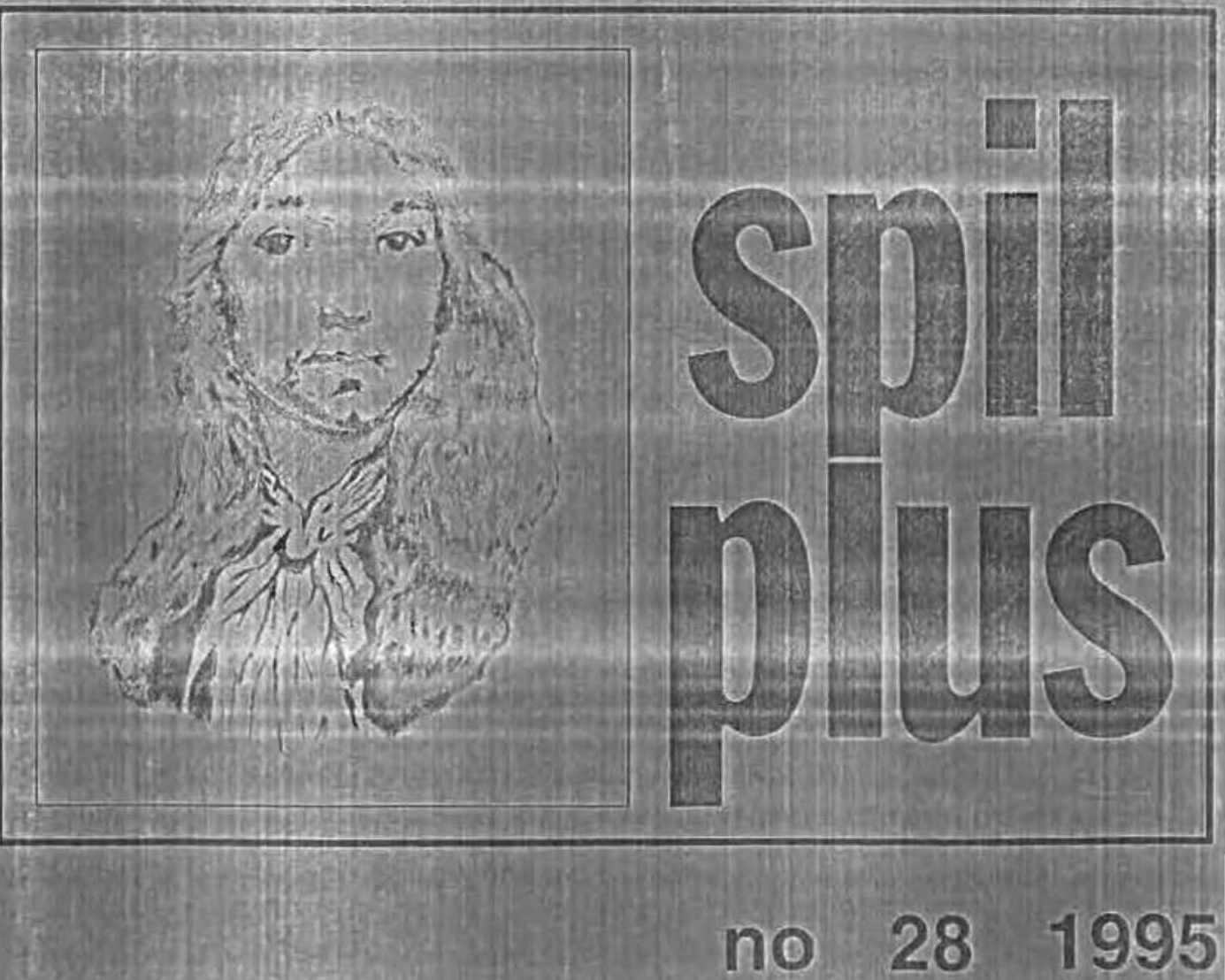


\section{THE WORLD OF LANGUAGE}

\section{ITS CODELIKE CORE}

by

Rudolf P. Botha

SPIL PLUS 28

1995 
This is the fourth of a series of studies painting a macroscopic picture of the architecture and dynamics of linguistic reality. It has to be read together with the first three, The World of Language. I Its Crust (= SPIL PLUS 24, 1994) and The World of Language. 2 Its Behavioural Belt (= SPIL PLUS 25, 1994) and The World of Language. Its Core ( = SPIL PLUS 27, 1995). Without the generous assistance of Walter Winckler, Theresa Biberauer and Christine Smit I would not have been able to complete the present study.

R.P.B. 


\section{CONTENTS}

$4 \quad$ Language and languages 1

4.1 Function 3

4.1.1 Instrumentality 3

4.1.2 Productivity 7

4.2 Form 7

4.2.1 Arbitrariness

$\begin{array}{ll}4.2 .2 \text { Principledness } & 10\end{array}$

4.2.3 Discreteness. 14

$\begin{array}{ll}4.2 .4 \text { Duality } & 17\end{array}$

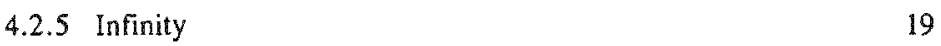

4.2.6 Structure-dependency 21

4.3 Structure 24

4.3.1 Hierarchicality 24

4.3.2. Discontinuity 30

4.3.3 Long-distance dependency $\quad 32$

4.3.4 Transformation 36

4.3.5 Pervasiveness of structuring $\quad 40$

4.4 Use 42

4.4.1 Autonomy $\quad 42$

4.4.2 Unusability 45

$\begin{array}{lll}4.5 & \text { Substance } & 48\end{array}$

4.6 The macroscope $\quad 52$

Notes to Chapter 4

$\begin{array}{ll}\text { Bibliography } & 60\end{array}$ 
Perhaps you too have been wondering all along about the Clubs. Why doesn't one bump into a King or a Queen of Clubs in Wonderland? The answer, I guess, is that Wonderland is not really a domain where just anything goes. On the contrary, for a dreamworld it is in many ways a pretty sane place. For example, it hasn't got room for a king or a queen of someone/thing if there isn't the corresponding someone/thing to be king or queen of. A 'monarch. without subjects' is, after all, conceptually an anomaly. So since Clubs are hard to. find (for whatever reason) among the card commoners populating this dreamworld, there can be no Queen or King of Clubs.

In the world of language, the same kind of sanity prevails. To see what this means, consider the idea of 'knowledge of language'. Obviously, in a sane world, someone cannot have knowledge of something unless there is the corresponding something to be known. Parallel to kings and queens who require subjects-to-be-ruled, knowledge requires objects-to-be-known. But this implies that, if there is a thing such as knowledge of language --- as has been claimed in par. 3.2 above --- there has to be something called langunge. Which is to say that conceptual necessity requires linguistic reality to have a fourth, deeper layer of objects: the layer of language in general and particular languages. It is with the ingredients of this layer -..- making up the core of the world of language --- that we will be concerned in the present chapter.

The general questions that we will take up sound misleadingly simple: 'What is language?' and 'What is a language?' For convenience, the two questions will on occasion be packed below into a single question, 'What is (a) language?' Which, as quesions go, turns out to be a real toughie. For one thing, it concerns the nature of entities that belong in the most deeply hidden layer of linguistic reality. For another thing, these entities, unlike Alice, could not speak for themselves if we were to ask them 'What are you?' When actually asked this question by the Pigeon --- who took her to be an egg-snatching serpent on account of the immense length of neck that she grew after eating a bit of mushroom -..- Alice replied:

'"But I'm not a serpent, I tell you!

... I'ma-I'm-"

To which the Pigeon responded impatiently:

"Well! What are you .... I can see you're trying to invent something!" [AIW 76] 
But, you may wonder, do we really have to do such an awful lot of inventing to arrive at an answer to the question 'What is (a) language?' Why, for instance can't we simply say: '(A) language is (i) whatever is known by someone who has knowledge of language, (ii) whatever is acquired by someone who learns (or "grows") a language, (iii) whatever is used by someone who produces, comprehends or intuitively judges utterances'? Whilst evidently true, this answer resembles the attempt by the Queen of Hearts to say what a Mock Turtle is:

"Then the Queen left off, quite out of breath, and said to Alice, "Have you seen the Mock Turtle yet?"

"No," said Alice, "I don't even know what a Mock Turtle is."

"It's the thing Mock Turtle Soup ${ }^{5}$ is made from," said the Queen.' [AIW 124]

This characterization of a Mock Turtle has to be admired as a product of fancy rhetorical footwork. 'Yet it is quite empty. Even if you know your food, you would have your work cut out to zome up with a mental picture of a Mock Turtle on the basis of the look, taste, and substance of Mock Turtle Soup." The portrayal of (a) language as that which is known, acquired, used etc, by speaker-listeners is about as far from informative as the Queen's characterization of a Mock Turtle.

So what can we do to get a more adequate answer to the question 'What is (a) language?'. One rewarding line of action is, firstly, to look at (a) language from the macroscopic perspective of the major dimensions of the world of language. And, secondly, to focus on the most salient large-scale properties that characterize (a) language in some of these dimensions. Here we will restrict our attention to the dimensions of function, form, structure, use and substance.

In pursuing the question 'What is (a) language?', we will have to keep in mind a distinction drawn in par. 1.1 .1 above: that between utterances and sentences. Spoken utterances, you may recall, are unique stretches of speech sound that are ingredients of the layer of language products. Sentences, by contrast, are non-physical entities that can be uttered more than once. As such, sentences are not to be found in the layer of language products. Below we will concern ourselves with the properties of sentences, not those of utterances. To identify and illustrate the properties of a sentence, however, it will always be necessary for ws to furnish some written utterance of the sentence (or, if you like, an utterance by which the sentence is realized in writing). 


\subsection{Function}

Soon after entering the world of language in par. 1, we were given some details about the Hatter's curious watch, the one that the March Hare dipped into his cup of tea to get some crumbs out of the works. Alice too found this watch rather 'funny' since:

'It tells the day of the month, and doesn't tell what o'clock it is! [AlW 96]

By describing what the Hatter's watch does and does not do, Alice gives us information about its function as well as some clues about its make-up. A watch not telling 'what o'clock it is' obviously won't have the hands, face or clockwork of a conventional watch. To find out what something is, it is generally good policy first to find out what it is for: that is, to find out its function (should it have one, of course). The function of a thing not only throws light on its nature, but often indirectly reflects the way in which it is put together and works. So, to tackle the question 'What is language?', let us consider first the function of language.

\subsubsection{Instrumentality}

One of the episodes in Alice's visit to Looking-Glass Country includes the following weird events:

- The White Queen turns into a bespectacled old Sheep which knits away busily behind the counter of a shop, using up to fourteen pairs of needles at the same time. [TLG 252]

- More or less simultaneously, the Queen's cry 'Oh, much better!' is tranformed -- via 'Much be-etter! Be-etter! Be-ee-etter!' --- into the bleat 'Be-e-ehh!" [TLG 252]

- A moment later, the shop becomes a little boat in which Alice and the old Sheep glide along between the banks of a river. [TLG 254]

. And the knitting-needles in their hands turn into oars. [TLG 254]

'Conversion' is clearly the name of the game in this episode. As a matter of fact, conversions of this confounding kind commonly occur in Lewis Carroll's worlds, contributing greatly to their dreamlike quality.

Conversions are basic ingredients of real worlds too, however, the world of language being a case in point. We have seen, for example, that the production of utterances involves the 
conversion, translation or mapping of messages into stretches of observable speech, writing or signing. ${ }^{2}$ In the case of speech production, the conversion can be broken up into at least the three clusters of processes shown by the numbered arrows in Figure 1:

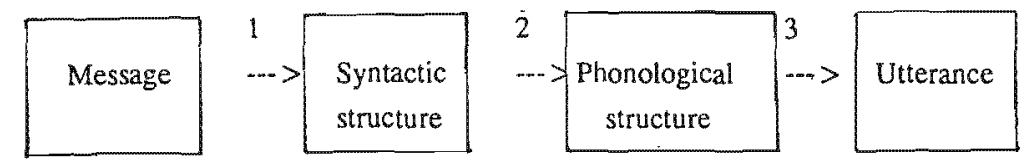

$1=$ grammatical encoding 2 = phonological encoding $3=$ articulating

\section{Figure 1: 'Prcductive' Conversion ${ }^{3}$}

Proceeding in the opposite direction, speech comprehension converts spoken utterances into the messages encoded in them. ${ }^{4}$ The conversion involved in speech comprehension is made up of the three clusters of processes shown by the numbered arrows in Figure 2:

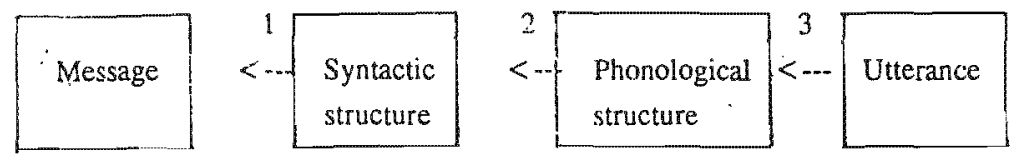

$1=$ interpretation/understanding $2=$ parsing $3=$ perception/recognition

Figure 2: 'Comprehensive' Conversion

So conversion is essential to both speech production and speech comprehension. ${ }^{5}$ But the kind of conversion that occurs in speech production/comprehension and the kind that happens in Carrollinian dreamworlds are as different as chalk and cheese. The Carrollinian kind boggles the mind: it is clear neither why these conversions occur nor how they work. There is nothing systematic governing, for example, the conversion of a queen into a sheep. This is to say that the occurrence, nature, direction, input, outcome and so on of dreamworld conversions are quite mysterious.

The conversion that occurs in speech production and comprehension, by contrast, is not of this mind-blowing kind. There is a principled means -..- portrayed as a code by some -.- that people use in a non-mysterious way in converting their messages into utterances and vice versa. This means is called language. To put it schematically: 

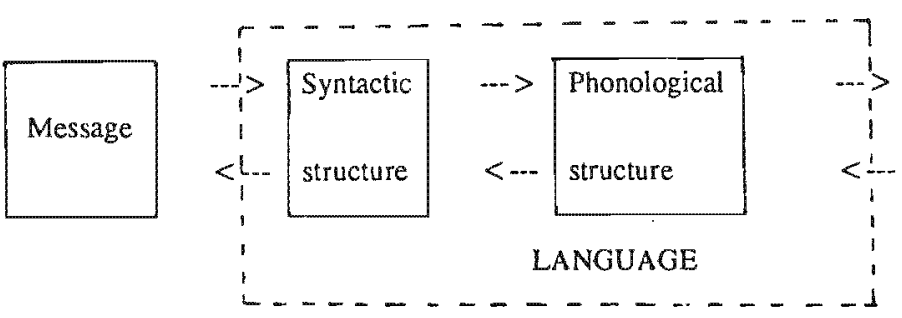

Figure 3: Language

Each different language is a different instantiation of the general means involved in the conversion of messages into utterances and vice versa. To know a language, then, is to have at your command a particular means used in the conversion of messages into utterances and vice versa. To the way in which (a) language is involved in this conversion process, we will turn in par. 4.2 .2 below. 6

Over the years, the essence of this functional characterization of language has been expressed by different scholars in different but basically equivalent ways. Recently, Noam Chomsky has described a language as a particular way of expressing thought and understanding the thought expressed. And, using more technical terms, he has characterized a language as a particular generative procedure: a procedure that assigns to every possible expression of the language a representation of its form and a representation of its meaning. The idea that a language is a generative procedure has its roots, as Chomsky emphasizes, in the thinking of Wilhelm von Humboldt. This famous German scholar of the nineteenth century characterized language as an Erzeugung, freely translatable as 'a process of generation', which makes infinite use of finite means. 7

Retuming to Figure 3 , the means offered by (a) language for converting messages into utterances and vice versa are of two kinds. First, there are the structures enclosed in the 'unbroken' boxes: syntactic and phonological structures representing intermediate 'steps' in the conversion of messages into utterances and vice versa. Second, there are the entities represented by the arrows: the mechanisms involved in the conversion of messages into syntactic structures and vice versa, syntactic structures into phonological structures and vice versa, and phonological structures into utterances and vice versa. As we saw in par. 3.2.2.1, these mechanisms are of two general kinds: words or lexical items making up the lexical aspect of language, and rules and 'super-rules' forming the combinatorial or computational aspect of language. 
To see this skeletal picture of the make-up of language in the right perspective, we make another foray into Looking-Glass Country, dropping in on a particularly instructive conversation between Alice and a chicken-sized Gnat [TLG 222-223]. At issue: Alice's rather nariow conception of (the names of) insects. Contrary to what she believes, the giant Gnat tells Alice, there is not only the ordinary Horse-fly, but also the Rocking-horse-fly (made entirely of wood and living on sap and sawdust). Not only the ordinary Dragon-fly, but aiso the Snapdragon-fly (whose body is made of plum-pudding, whose wings consist of holly-leaves and whose head is a raisin burning in brandy). And not only the ordinary Butterfly, but also the Bread-and-butter-fly (whose wings are thin slices of bread-and-butter, whose body is a crust, and whose head is a lump of sugar). One of the general points implicitly being made by the Gnat is that there are not only narrower (pcorer, less inclusive, more limited) conceptions of things, but also wider (richer, more inclusive, less limited) conceptions of them. Indeed, part of the reason why Alice finds the dreamworlds she visits so utterly bewildering lies in the narrouness of her own conceptions of things (and events).

The distinction between narrower and wider conceptions of things does not, however, apply to dreamworlds only. It applies equally to real places such as the world of language. Thus, the conception of language represented schematically in Figure 3 above is in more than one way quite a narrow one. For example, on this conception, language includes grammar only. Which is to say that language is narrowly taken to equal the object of knowledge of grammar or of grammatical competence. Recall that knowledge of language has, however, two more components: pragmatic competence (or knowledge of appropriate use) and the conceptual system (or knowledge of how to build and reconstruct messages). This is to say that firstly, on a less narrow conception of it, language has an additional component that is 'Rocking-horsefly'-like, comprising principles of appropriate use. Secondly, language has a component that is 'Snap-dragon-fly'-like, including means of message construction and reconstruction.

Grammar itself too can be thought of in less restrictive terms. On one possible richer conception of it, linguists have been taking grammar to include more than one intermediate 'step' (or level) of syntactic structure and more than one intermediate 'step' (or level) of phonological. structure. And, this conception of grammar they have further enriched by supposing a kind of 'Bread-and-butter-fly'-like structure, often called 'semantic structure', to mediate in the conversion of messages into syntactic structures and vice versa. ${ }^{8}$ 


\subsubsection{Productivity}

Language, few will deny, allows people to talk about everything under the sun and even about things in worlds located light years beyond the sun. What is more, language enables people to talk about extraordinary things such as those found in the dreamworlds visited by Alice. You will recall that language enables them to say things about some really curious creatures. Blue hookah-smoking caterpillars. Thin-skinned (or rather 'thin-shelled') eggs wearing cravats. Bloodthirsty Queens of Cards. Professorial whales each wearing a gown and mortar-board. Siamese twin-cats speaking in tandem. And so on, and so on. Language enables people to describe extraordinary events such as girls growing to be ten feet high, babies turning into pigs, cats disappearing to leave only their grins behind and so forth. In sum: there is nothing that people can think up that they cannot express by producing linguistic utterances. That is to say, the use of language is unbounded in scope -.- a feature of language use that contributes greatly to the creative aspect of language behaviour, as we saw in par. 2.2 .5 above.

But how is it possible for language use to be unbounded in scope? Part of the answer is that, as a means of converting messages into utterances and vice versa, language itself has a particular functional property: it is productive. This means that, whatever the human thought or message, human language enables us to convert it into an (acceptable) utterance. By the same token, every (acceptable) utterance can be converted with the aid of this means into a thought or message. These points are captured by some linguists by means of the concept of 'effability'. Specifically, they claim that the 'essential' property of languages is that their grammatical structure constitutes an effable correlation of sentences and senses (or meanings). In the solemn kind of phraseology found so irresistible by the Dodo, this implies that there will never be a case where a speaker is unable to express a thought because of the non-existence of an appropriate sentence or a sense. Or, to put the point more positively, there will always be sufficient sentences and senses. 9

But how is it possible for language to be productive? What is it that makes language the productive means that it is? As we proceed, we will see how this productivity springs from certain non-functional properties of language.

\subsection{Form}

Knowing the function of something $S$ does indeed give one a better understanding of the nature of $\mathrm{S}$. But to understand its nature more fully, one has to look directly at its clockwork. This 
means that we have to train our macroscope on the words or lexical items, on the rules and on the 'super-rules' as well as on the structures involved in the conversion of messages into utterances and vice versa. We will be concerned with the large-scale properties of these generative mechanisms, which is to say that we will be focusing on the form of language.

\subsubsection{Arbitrariness}

The words making up the vocabulary or lexicon of language is a first source of its productivity. But exactly what is it in the nature of words that boosts the productivity of language? The way in which Humpty Dumpty treats the words that work for him sheds quite a bit of light on the matter: he makes them man just what he chooses them to mean --- 'neither more nor less' [TLG 269]. For example, despite Alice's misgivings, Humpty makes the word glory mean "a nice knock-down argument'. And he makes impenetrability mean 'we have had enough of that subject, and it would be just as well if you'd mention what you mean to do next, as I suppose you don't mean to stop here all the rest of your life".

But how is it possible for Humpty to make words mean what he chooses them to mean? Contrary to what he claims, it isn't the extra wages he pays them that do the trick. What does do the trick is that ite himself rather (cleverly) exploits the nature of the relation between the sound form of a word and its meaning. This is a relation of arbitrariness: in the case of the overwhelming majority of words, there is no principled reason why a given form and a given meaning are paired. For example, there is no reason why the sound form of the word glory has to mean something like 'the fame and admiration that you gain by doing something notable'. Nothing in this sound form requires it to be paired with this meaning. Conversely, nothing in this meaning requires it to be associated with the sound form of glory. The same remarks apply, of course, to impenetrability. It is the arbitrariness of the link between their sound form and their meaning that enables Humpty to assign a new meaning to words such as glory and impenetrability --- nothing in their sound form makes it impossible for them to be assigned such new meanings.

The pairing of forms and meanings is established by convention in all but a restricted number of words. The latter words ..- as exemplified by woof, meow, cockadoodledoo and other onomatopoeic items -.- are iconic: their sound forms are believed to be related by some physical resemblance or other to what they 'stand for'. Glory, impenetrability and the vast majority of other words, by contrast, are symbolic: their sound forms are related by convention to what they 'stand for'. Foregrounding this fact, quite a number of linguists have portrayed language as a symbol(ic) system. This conception of language had its origins in the 
thought of the Swiss linguist Ferdinand de Saussure, who has been credited with formulating the 'principle of the arbitrariness of the linguistic sign. 10

The arbitrariness of the link between the form and meaning of words contributes to the productivity of language in more than one way. First, speaker-hearers can add new words to the lexicon of their language without having to agonize over the question whether a particular form is 'right for' or a 'good match for' a particular meaning and vice versa. The author of Jabberwocky, for example, had no need to worry about whether the form of toves is the 'right' or the 'best' form for the meaning 'badgers with smooth white hair, long hind legs and short horns like a stag, living chiefly on cheese'. Nor was it necessary for him to find a principled reason for pairing the meaning 'land turtles with an erect head, a mouth like a shark, forelegs curved so that they walk on their knees, a smooth green body and living on swallows and oysters' with the form of raths [TLG 191]. Incidentally, although Humpty understood the arbitrary nature of the link between word form and word meaning, he was rather confused about the meaning of proper names. He believed that 'Humpty Dumpty' meant 'the shape he was in' and that, like his own name, all other names must mean something. And he chided Alice for having a 'stupid' name: a name that had no meaning and that consequently allowed her to be 'in any shape, almost'. [TLG 263]

Second, the arbitrariness of the link between the form of a word and its meaning makes it possible for speaker-hearers to have words denoting abstract, non-material 'things' such as glory, anger, minds, dreams and so on. And also words for denoting nonexisting creatures such as unicorns, gryphons and other denizens of nonreal places such as the universes of fairy tales, science fiction and so. Had the relation between word form and word meaning been nonarbitrary or natural, it would not have been possible to have words denoting abstract or nonexistent entities: the forms of words are by their very nature concrete existing entities. Not even in Wonderland do we find creatures speaking a kind of language whose laws require that words denoting abstract entities are to have abstract forms, or words denoting non-existent entities are to have non-existent forms!

There is a price to pay, however, for the arbitrary and conventional nature of the link between the form and meaning of words. People acquiring a language have to learn its words by rote, a factor which places quite a burden on their memory. This can be particularly taxing when learning the lexicon of a second or foreign language in which (more or less) known meanings are arbitrarily associated with (more or less) unfamiliar forms. The problems caused for language learners by an arbitrary relation between the form and meaning of words are heavily 
outweighed, however, by the ways in which such arbitrariness contribute to the productivity of language. 11

\subsubsection{Principledness}

The main source of the productivity of language, however, is located in the nature of grammatical rules and linguistic 'super-rules' or universals. Grammatical rules are linguistic principles that are specific to individual languages. The following three examples are peculiar to English (and a few related other languages):

1 A (declarative) sentence consists of a Noun Phrase followed by a Verb Phrase.

2 In a Verb Phrase, the verb precedes the role-bearing phrases.

3 To form a yes/no question, switch the subject Noun Phrase of the main clause and its Auxiliary. 12

Linguistic universals, by contrast, represent linguistic principles that are independent of individual languages. In par. 3.3 above, we considered the following examples:

4 The operations expressed by grammatical rules such as 3 are structuredependent.

5 If (a) $X$ and $Y$ are explicit or understood components such as names, pronouns, anaphoric elements, etc.,

(b) $\mathrm{X}$ is a component of a main clause and $\mathrm{Y}$ is a component of a clause embedded in this main clause, and

(c) the embedded clause has a subject which is distinct from $Y$, then $X$ and $Y$ cannot be linked by a linguistic rule.

6 A phrase consists of a head word and, amongst other things, a number of smaller, role-bearing phrases. 13

But in what sense are grammatical rules and linguistic universals involved in the conversion of messages into utterances and vice versa? To forestall a possible misunderstanding: such rules and universals do not represent the neurological, physiological or physical processes which actually happen as speakers convert messages into utterances or hearers convert utterances into messages. This implies, amongst other things, that these rules and universals are not intended to model concrete aspects of the structure and dynamics of the human brain. Rather, they are thought to govern this process of conversion (and to govern it) without forming part of it. Grammatical rules and linguistic universals represent what is principled or lawful at an abstract 
level in the conversion of messages into utterances and vice versa. So, in the case of a specific rule or universal, what does this boil down to?

Consider once more rule 3: 'A (declarative) sentence consists of a noun phrase followed by a verb phrase'. This rule makes a number of distinctions, including the following:

7a sentences (as well-formed sequences of words) vs. things that are non-sentences

b declarative sentences vs. non-declarative sentences

c Noun Phrases vs. Verb Phrases

d following vs, preceding

Rule 3 governs the conversion of messages into utterances and vice versa by requiring that, at some stage, this conversion somehow must also make (at least) these four distinctions. Unless the conversion process did just this, it would not be able to match messages and utterances effectively, as is made clear in $8 \mathrm{a}-\mathrm{d}$ below:

8 Unless the distinction of $7 \mathrm{a}$ is made, the processes of conversion may try (unsuccesfully) to convert the ill-formed sequence of words Queen Executioner the the fired into some message.

$\mathrm{b}$ Unless the distinction of $7 \mathrm{~b}$ is made, Has the Executioner been fired by the Queen? may erroneously be regarded as an utterance of an ill-formed declarative sentence which cannot be converted into a message. It is, in fact, an utterance of a well-formed question.

c Unless the distinction of $7 \mathrm{c}$ is made, the deviant utterance The Queen the Executioner may erroneously be regarded as an utterance of a declarative sentence. It is, in fact, an utterance of a sentence which incorporates a Noun Phrase (the Executioner) where it should have had a Verb Phrase (e.g., fired the Executioner).

d Unless the distinction of $7 \mathrm{~d}$ is made, the utterance Fired the Executioner the Qucen would erroneously be considered as an utterance of a well-formed declarative sentence with which a meaning has to be associated. The sentence is ill-formed since the Verb Phrase (fired the Executioner) follows rather than precedes the Noun Phrase (the Queen).

So here is the point: Grammatical rules, such as $1-3$, and linguistic universals, such as $4-6$, engage in the process of conversion by expressing lawlike constraints that have to be obeyed at the level of function by the processes that actually engage in the conversion of messages into 
utterances and utterances into messages. These rules and universals have the 'job', in other words, of making sure that messages and utterances are matched correctly.

In a sense, grammatical rules and linguistic universals are the laws of language. To see the point of the qualification 'in a sense', consider the curious way in which Alice tumbled into Needle's Eye World:

'As she fell, her body would sometimes turn upside-down, so that earth and sky changed place, and the neatly tilled freld seemed to hover high above her head. "What a curious adventure this is, to be sure!" said Alice. "I'm certain I must be breaking the Law of Gravity: for, if I remember my lesson, it states that what goes up must come down - yet here am I clearly coming down -" without ever having gone up'. [TNE 8]

Alice's breaking 'the Law of Gravity' is a rather remarkable achievement, a feat possible in a dreamworld only. In real worlds, after all, physical laws cannot be broken, disobeyed, suspended, or the like. This is where the laws of language are different and why -- - compared to laws of naure --- they are laws 'in a sense' only. People can break at will those laws of language of which they are or can become conscious. (As we have seen, the knowledge which linguistically untrained people have of (the laws of their language is tacit only. ${ }^{14}$ ) A speaker of English who consciously knows grammatical rule 1, for instance, can break it to produce an utterance such as 'Fired the Executioner the Queen in which the Verb Phrase 'unlawfully' precedes the Noun Phrase. Similarly a speaker can violate linguistic universal 4, for example. Given a statement, say The Hatter who is mad is innocent, the speaker can violate linguistic universal 4 by forming the corresponding yes/no question in a structure-independent way, namely as *Is the Hatter who mad is innocent? But there is a price to pay for breaking the laws of language: difficulty in getting your messages across if you, are a speaker or difficulty in recovering other people"s messages if you are a listener.

A sizeable section of the population of Looking-Glass Country was made up of chess pieces: two Kings and two Queens, various Castles (two of which Alice saw walking arm in arm), a number of Pawns (of which a White one, the Queen's baby, rolled over and started to kick and cry), two Knights (who banged away at each other with clubs), some Horses (one of which wore anklets to protect its feet against shark bites) and so on. This wasn't all that strange since, as Alice told herself, Looking-Glass Country was marked out just like a large chess-board. And, she added in a tone of delight: 
"there ought to be some men moving about somewhere - and so there are!... It's a great huge game of chess that's being played - all over the world - if this is the world at all, you know". ' [TLG 207-208]

But if a place is actually a chess-board and the events occurring in it are in essence moves in a game of cless, there simply have to be chess-pieces among its surface population. These pieces (or characters) are in a sense 'derivative' or 'epiphenomenal' entities: their existence is an automatic result of the dreamworld's deeper architecture and deeper dynamics.

Rather like Looking-Glass chess-pieces, grammatical rules may well in a specific sense be derivative entities or epiphenomena too. In the late seventies, Noam Chomsky has in fact suggested that such rules result automatically from events that involve deeper entities. Specifically, he portrays language as being a system of principles with open parameters. Individual languages differ in how the open parameters are fixed, set or filled in. A rule of grammar, on this conception, represents a specific parameter fixing or setting. This point was illustrated in par. 3.3.4 with reference to principle 9 (first considered above as linguistic universal 6).

9 A phrase consists of a head word and, amongst other things, a number of smaller, role-bearing phrases.

This principle has an open parameter involving the relative positions of the head word and rolebearing phrases. In the case of the verb phrase gave the stolen larts to Alice, the head word is the verb gave, which precedes the role-bearing phrases the siolen tarts and to Alice. English, clearly, fixes the relevant open word-order parameter by choosing the 'head first' option. This parameter-fixing can be expressed derivatively as a grammatical rule:

10 In a Verb Phrase in English, the verb precedes the role-bearing phrases (if any).

Japanese, however, fixes the open word-order parameter of principle 9 in a different way, namely by choosing the 'head last' option. This parameter-fixing can be stated derivatively as a grammatical rule too:

11 In a Verb Phrase in Japanese, the verb follows the role-bearing phrases (if any).

Clearly, grammatical rules such as 10 and 11 are not basic entities. They represent "shallow", derivative entities or epiphenomena resulting from something (parameter-fixing) that happens 
to deeper entities (principles with open parameters). On this view, an individual language is not in essence a rule system; it is rather a system of fixed parameters (or, if you like, parameterfixings). 15

\subsubsection{Discreteness}

But what is it in the nature of grammatical rules and 'super-rules' that makes language such a productive means of linking messages to utterances and vice versa? Let us pursue this question by going back to an incident in Wonderland in which Alice drank a strange fluid that shrunk her to a mere ten inches. The fluid had an extraordinary flavour, described by Alice in the following way:

'... it had in fact a sort of mixed flavour of cherry-tart, custard, pine-apple, roast Turkey, toffy and hot buttered toast. '. [AIW 3I]

It is clear that Alice did not taste (or smell) cherry-tart, custard and so on as distinct ingredients of the fluid. These ingredients, obviously, were blended in the fluid, her description being suggestive of the general flavour of the blend. The properties of a blend lie in between the properties of the ingredients; the properties of the ingredients are lost in the mixture. In short, in a blend, the ingredients become indistincl.

Compound linguistic expressions such as the sentence (underlying the utterance) Alice watched the Cat are not blends. They are made up of a finite number of discrete elements -..- the words Alice, watched, the, Cat --- and their properties do not lie somewhere in between the properties of these elements. For example, the meaning of Alice watched the Cat is distinct from the meaning of any of the words of which it is made up. And the meaning of this sentence is distinct from that of The Cat watched Alice in which the same words are combined differently.

But in what sense can the words making up a sentence be considered discrete? In the sense that they remain identifiable as distinct units which can be recombined to form other sentences. That is, when words are put together into sentences, they are not irretrievably mashed together. Sentences can always be broken down again into individual words. A sentence is therefore never a 'continuum' in the sense of a thing that is without parts and the same from beginning to end. The words making up a sentence remain identifiable since they contrast with other words. Thus, in The Cat watched Alice, the contrasts, for example, with a, Cat with Queen, watched with licked and Alice with Mabel. 
Similarly, the (sound) forms of words are not indivisible streams/bursts of noise. For example, the form of the word $C a t$ can be segmented into three distinct speech sounds represented by $C$, $a$ and $t$. And because of their discreteness, these sounds can be (re-)combined in other orders to build other word forms --- those of act and tack in particular. (In English spelling, the letter $c$ of cat and the letter pair $c k$ of tack represent the sarne speech sound.) The discreteness of speech sounds ties in with the fact that they are used to contrast with each other in certain positions in the forms of words in order to distinguish those forms from each other. For example, the sound represented by $c$ contrasts with the one represented by $g$ at the beginning of the form of cat. And there isn't a distinct English speech sound between $c$ and $g$, one which is 'not quite' $c$ or 'almost' $g$, though it is possible for speakers of English to produce such a sound. It is because $c$ contrasts with $g$ in certain positions in word forms that speaker-listeners identify $c$ as a distinct speech sound in a form such as that of cat. In terms of the relation of contrast, speech sounds have to be either distinct or identical, and simply cannot be 'somewhat', 'a lot' or 'almost' like each other.

As units used for distinguishing the form of words, speech sounds are, as a matter of fact, not noises. As we saw in par 1.1.1 above, noise is an ingredient of the layer of language products: the signal of spoken utterances exists (fleetingly) as noise. Speech sounds -...- or phonemes, as they are also known --.- are entities found in the layer of language where they serve to distinguish the forms of words that are building blocks of sentences. It is when sentences are produced as utterances that noises are made which correspond, though in an indirect way, to speech sounds. Likewise, the layer of language behaviour and the layer of knowledge of language also contain entities that correspond to speech sounds. In the layer of Ianguage behaviour, these corresponding entities are the acts of making and perceiving the noises that correspond to speech sounds. In the layer of knowledge of language, what corresponds to speech sounds is of course the speaker-hearers' tacit knowledge of how to perform those acts -- articulatory and perceptual ... that correspond to speech sounds. The place that an individual speech sound such as t has in the world of language can, in sum, be represented with the aid of the following figure: 


\begin{tabular}{|l|l|}
\hline Layers & t \\
\hline Language products & The physical noise \\
\hline Language benaviour & $\begin{array}{l}\text { An act of making the noise } \\
\text { An act of perceiving the noise }\end{array}$ \\
\hline Knowledge of language & $\begin{array}{l}\text { Knowledge required for making the noise } \\
\text { Knowledge required for perceiving the noise }\end{array}$ \\
\hline Language & The (known) distinctive speech sound \\
\hline
\end{tabular}

Figure 4

On the whole, animal communication systems are unlike human languages in regard to discreteness. The signats --.- noises, movements, postures, gestures, colours, odours --- used by animals to communicate something are generally non-discrete. That is to say, these signals carnot be subdivided into contrasting repeatable units that correspond to the recombinable sounds or words of human language. When the White Queen's exclamation 'Oh, much better!' is transtormed into the old Sheep's bleat 'Be-e-ehh!', something discrete is turned into something non-discrete or continuous.

The fact that sentences are not blends, but instead are discrete combinations of discrete elements, reflects a fundamental property of the system of rules of a language. This system is an example of a discrete combinatorial system. By means of such a system, a finite number of discrete elements can be manipulated --- sampled, combined, permuted -..- to create larger units or structures whose properties are distinct from those of the elements. A language, by implication, is not an example of a blending system. Blending systems -.. such as the one used for mixing the strange fluid that Alice drank -.- allow the creation of combinations or compounds whose properties lie in between those of the elements which lose their individual properties in the resulting blends or mixtures.

Animal communication systems that use non-discrete signals are examples of graded systems. With such systems, the user produces new messages by changing the signal along some physical dimension. Changes in intensity, duration and so on signal parallel changes in the message. For example, by varying the intensity of its roar, a rhesus monkey can signal how 
aggressive it is: greater loudness signals greater aggression. And by varying the duration of its tail-wagging dance, a honeybee can signal the distance of a food source: the longer the bee takes over a certain part of the dance, the further the food source is from the hive.

The productivity of (a) human language benefits in no small way from its discreteness. For one thing, a language does not need to provide each of its users with a completely different sentence for expressing each new message. Rather, it serves its users by placing at their disposal differing combinations of discrete, existing words -...- words coming from a limited stock. For another thing, the words belonging to this stock - the lexicon -... do not need to have sound forms which are tolally unlike. Rather, these sound forms can be different (re)combinations of discrete speech sounds drawn from a quite limited inventory. This means, among other things, that a speaker-hearer can use tens of thousands of distinct word forms without having to be able to produce or discriminate among tens of thousands of different speech sounds. In the case of English, being able to produce and discriminate among about forty distinct speech sounds is all that is needed. Which is something that even the Red Queen would find hard to sneer at! 16

\subsubsection{Duality}

While looking at the discreteness of language, we had a passing glimpse of another of language's fundamental properties, namely duality. Or at least of the long shadow which duality casts. But by this time, you will have grown wary of the existence of entities 'seen in passing' only, recalling the case of Nobody -..- the individual who, despite his non-existence, was encountered on the road by one of the King's Messengers. Which caused the King to attribute to the non-existing Nobody the property of being a slow walker. Agreeing with you that one Nobody is enough, I suggest, then, that we face duality head on.

Language exhibits duality in that it is patterned or organized at two levels which are distinct from each other and yet hang together in a particular way. At the first or higher level, sentences or phrases are built up out of meaningful words (or lexical items). As we have seen just above, at the first level, a sentence like Alice watched the cat is made up of meaningful words like Alice, watched, the and cat. At the second or lower level, the forms of these (inherently) meaningful words are built up out of (inherently) meaningless speech sounds. At this level, the form of the word cat, for example, is made up of the speech sounds representable by the letters $c, a$ and $t$, respectively (and arranged in that order). If English had lacked duality, the form of a (meaningful) sentence would be directly built up out of (meaningless) speech sounds. 
To say that language is characterized by duality is to say that it does not use just one combinatorial system of rules. It is to emphasize that language in fact uses two such rule systems. The first is for building phrases and sentences out of meaningful words. The rules 1 and 2 above and 25 a-e below are rules of this sentence-building kind. The second combinatorial rule system builds word forms out of meaningless speech sounds. These rules include phonotactic rules (or conditions) which specify what sequences or combinations of speech sounds may or may not occur where in word forms. The phonotactic rules, then, can be thought of as word-form laws, the following two being examples used in English:

12a The sounds $l$ and $b$ can combine in this order at the end but not the beginning of a word form.

$b$ The sounds $b$ and $r$ can combine in this order at the beginning but not the end of a word form.

Rule 12 a allows speakers of English to build a (new) word form such as $d u l b$, but not one such as lbud. Rule 12b allows Lewis Carroll to build a (new) word form brillig, but not one such as gillibr. Not one of the new words he uses in Jabberwocky breaks the phonotactic rules of English.

Duality links with both discreteness and arbitrariness to boost the productivity of language. In tandem with discreteness, duality makes it possible to combine a small number of meaningless speech sounds for building forms for a very large number of meaningful words, a point mentioned with reference to discreteness -.- the partner of duality -- in par, 4.2 .3 as well. Arbitrariness, in turn, opens the way for duality to make its contribution. To see how, suppose that each speech sound in the form of a word had to be linked in a non-arbitrary way to some bit of the meaning of the word. This would have severely restricted the ability of speech sounds to combine with each other. Take, for example, the (three) speech sounds that combine to make up the form of the English word stove. If these sounds had each been linked to some other bit of the word's meaning in some non-arbitrary way, they clearly could not be recombined by Lewis Carroll to build the form of the new word toves. Nor could these speech sounds be recombined to make up the form of the word votes. If each of these speech sounds had had a natural meaning, they clearly could not be used to build forms for words whose meanings differ so totally as those of stove, toves and votes. What arbitrariness does, then, is to keep speaker-hearers free from any meaning-based constraints whenever they build word forms out of individual speech sounds. 17 


\subsubsection{Infinity}

The discreteness of language interacts in an interesting way with another of its fundamental properties, namely recursiveness. To see what recursiveness involves, consider the following set of expressions:

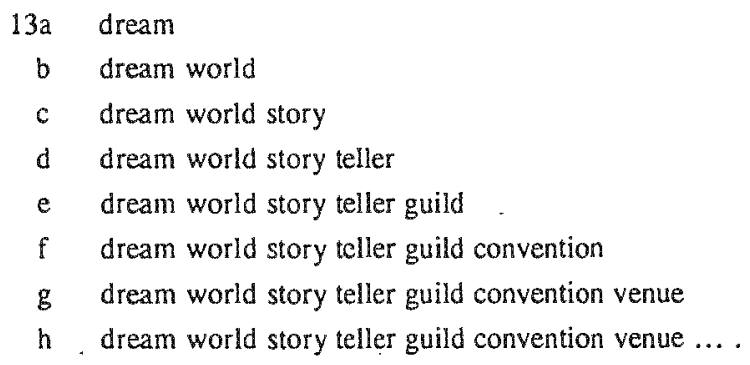

Expressions like $13 \mathrm{~b}$ - $\mathrm{h}$ are formed by a word formation rule that adds one noun (e.g., world) to another (e.g., dream) to form a compound noun or nominal compound (e.g., dream world). Such a rule can be applied 'recursively'; that is, it can be applied an unlimited number of times to its own output. For instance, the rule applies to $13 \mathrm{~b}$ to form $13 \mathrm{c}$, to $13 \mathrm{c}$ to form $13 \mathrm{~d}$, to $13 \mathrm{~d}$ to form $13 \mathrm{e}$ and so on. In other words, because it is able to feed itself an unlimited number of times, the rule has the capacity of forming an unlimited/infinite number of noun compounds.

Certain syntactic rules -.- that is, rules of sentence formation -.- have the property of recursiveness too, as is illustrated by the following set of sentences:

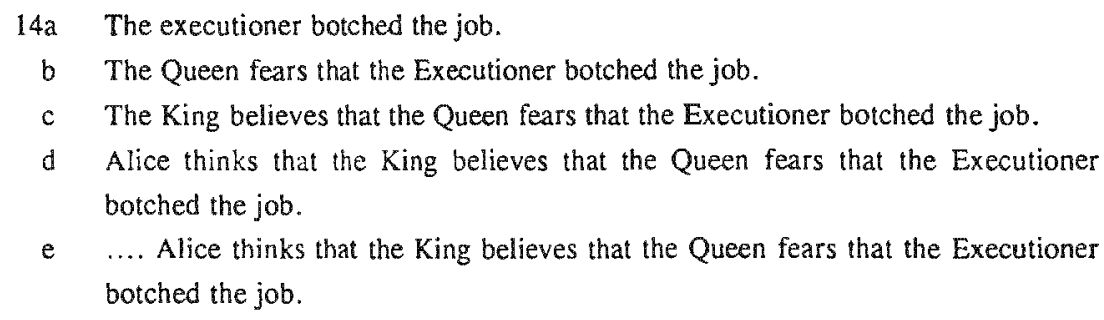

Sentence $14 \mathrm{~b}$ is formed by a syntactic rule that embeds sentence $14 \mathrm{a}$ within the 'mother' or matrix sentence The Queen fears ...; sentence $14 \mathrm{c}$ results when this rule embeds sentence $14 \mathrm{~b}$ within the matrix sentence The King believes ...; and so on. Like the word formation rule considered above, this syntactic rule can apply an unlimited number of times. Each application 
of the rule yields yet another sentence. This rule has the capacity of yielding an infinite number of sentences when applied in tandern with the rule(s) that create(s) the matrix sentences. Recursiveness, then, is the capacity of language to build an infinite number of units (words or sentences) from units of the same category. 18

Which brings us to how discreteness and recursiveness interact in language. A discrete combinatorial system allows the formation of units (sentences) that can be counted. A discrete combinatorial system having the property of recursiveness allows the formation of infinitely many units (sentences). Discreteness and recursiveness, therefore, interact to allow the construction of a discrete infinity of meaningful expressions.

The kind of infinity found in the world of language is quite unlike the mysterious kind that figures in Needle's Eye World. Some of Alice's companions suspected Infinity to be the place to which the never-ending tunnel out of the Maze led. Unable to form a clearer idea about the nature of Infinity, Alice herself speculated about Infinity along the following lines:

'"Infinity, now .... al! I know about it is that it looks like an 8 that was so tired, it simply had to lie down and take a nap. And it's where parallel lines meet, isn't it, and what a queer sight that must be! I wonder how they greet one another after such a long separation. Most people say 'Isn't it a small world!' but that wouldn't do at all. They'd say 'Isn't it a large world", rather." [TNE 130-131]

The infinity, that characterizes language, namely discrete infinity, is of a less enchanting kind than the infinity that Alice was musing about. But our understanding of discrete infinity is 'infinitely' better, as is clear from the lucid way in which Noam Chomsky has characterized it:

"To put it simply, each sentence has a fixed number of words: one, two, three, fortyseven, ninety-three, etc. And there is no limit in principle to how many words the sentence may contain.'

Every time a sentence is extended through the addition of one or more words, one more distinct sentence is formed. This observation forms the basis for Chomsky's early characterization of a language as an infinite set of sentences. 19

Noam Chomsky considers discrete infinity to be a basic property of language, one that is unusual among biological systems. None of the animal communication systems known to Chomsky have this property: these systems are either nondiscrete or finite. The difference 
between human language and animal communication systems is one of quality, not one of 'more' or 'less'. In identifying discrete infinity as a basic property of language, Chomsky has an illustrious forerunner, Wilhelm von Humboldt. About a hundred and fifty years ago, Humboldt came to understand that language is a system that makes infinite use of finite means. Today this insight can be captured in a more precise way with the aid of the concept of 'discrete infinity'.20

\subsubsection{Structure-dependency}

In par. 4.2.2 above, we once again bunped into the idea that grammatical rules are structuredependent. So it's time for us to look a bit more closely at structure-dependency (or dependence) as a fundamental property of language. This will lead us to a consideration of various other structural properties of language. It is possible to get a better grasp of the idea of structure-dependency by considering some of the woes of the professional life of the Queen's first executioner, now referred to simply as 'Ex-ex'. (You had no idea that the incumbent Executioner is a new boy?) Well, Ex-ex and the Queen did not exactly get on like a house on fire. He resented her 'mindless meddling' in his professional business ('It is better to be headless than mindless', he would often mutter under his breath.). She, in turn, threatened him with beheading (!), having him 'cut down to size' for 'being too clever by half'.

This disharmonious relationship had its roots in deep differences of opinion about how Ex-ex should go about selecting, from among those awaiting his attentions, 'the next victim for the administering of injustice', as he cynically put it. Desiring no more (and no less) than fast and furious action, the Queen urged him 'to line up the lot, to start with the first, and not to skip anybody in the queue'. This advice was firmly rejected by Ex-ex, since 'it would place me on a par with brainless butchers'. A sentiment to which the Queen responded apoplectically, shouting that if he had to be so smart, he should use the following rule (and should, above all, get on with the job):

\section{The Queen's Rule}

'Find every fifth condemned clod in the queue and move him/her to the front.'

Judging this rule to be 'too undiscriminating' ('It would appeal to serial killers only!'), Ex-ex proceeded to select 'my next charge' on the basis of his own rules, which he varied from day to day: 


\section{The Executioner's Rules}

'Find the dumbest Knave (i.e., the one who didn't steal the Queen's tarts), and move him to front of the queue."

'Find the Gardener who was the best at painting the Queen's white roses red, and move him to front of the queue.'

'Find the soldier who didn't walk off wlyen he had to stand on his hands and feet as an arci in the Queen's croquet game, and move him to front of the queue."

The rules followed by Ex-ex differ in an interesting way from the one proposed by the Queen. In terms of the Queen's rule, a 'condemned clod' gets moved to the front of the queue, if he/she is found in a place that can be determined by simply counting those lined up for execution. And he/she gets moved, regardless of his/her status or rank or how he/she is related to his/her companions in the queue. The rules followed by Ex-ex have a completely different nature: a condemned creature gets moved to the front if it is a particular kind of individual (e.g., a Knave) related in a certain way (e.g., in terms of dumbness) to its condemned companions.

In the learned language of the Dodo, the basic difference between the Queen's rule and those of Ex-ex is that between simple linearity and status or structure. The Queen's rule treats a queue of condemned creatures as a simple linear series of individuals who are equal in status. The rules of Ex-ex, by contrast, treat a queue of condemned creatures as a series with a structure: a structure that reflects the differences in category and/or status among those who form the queue and also the different ways in which they interrelate. This makes a Knave, for example, different from a Pawn or a Knight. Also, it accords the dumbest Knave a higher status .... in the dumbness hierarchy ... than the other Knaves. In terms of the rules followed by Ex-ex, the condemned creature selected for movement to the front of the queue must specifically be the most prominent person in some hierarchy. So, the operation of movement specified by the rules of Ex-ex is dependent on the structure of a series of entities. In other words, these rules have the property of struclure-dependency. The Queen's rule specifies a structure-independent operation and has the property of structure-independency: (All of this, of course, was wasted on the Queen who, unable to get Ex-ex to behead himself, demoted him to woodcutter.)

Which brings us to the nature of rules of sentence formation: language uses structure-dependent syntactic rules despite the fact that they are less simple than structure-independent ones. This is illustrated strikingly by the English rule for the formation of yes/no questions (henceforth: the yes/no question rule) such as $15 \mathrm{~b}$ and $16 \mathrm{~b} .21$ 
15a The Queen is in a purple rage

b Is the Queen in a purple rage?

16a The Executioner is a woodcutter now.

b. Is the Executioner a woodcutter now?

The following looks like the simplest rule for forming yes/no questions such as $15 \mathrm{~b}$ and $16 \mathrm{~b}$ :

17 Find the first occurrence of the verbal form is (or others like it), and move it to the front of the sentence.

This rule is very simple indeed: it considers linear order only; it inspects the individual words of a sentence until it finds the first is or similar other word; that word it then moves. But rule 17 runs into trouble in the case of the yes/no questions corresponding to declarative sentences such as $18 \mathrm{a}$ and 19a. Applying it in the above way, rule 17 incorrectly forms $18 \mathrm{~b}$ and $19 \mathrm{~b}$ as the yes/no questions corresponding to $18 \mathrm{a}$ and $19 \mathrm{a}$, respectively. The respective correct yes/no questions are of course $18 \mathrm{c}$ and $19 \mathrm{c}$ :

18a The Queen, who is dumb, is in a purple rage.

b * "ls the Queen, who dumb is, in a purple rage?

c Is the Queen, who is dumb, in a purple rage?

19a The Executioner, who is an intellectual, is a woodcutter now.

b *Is the Executioner, who an intellectual, is a woodcutter now?

c Is the Executioner, who is an intellectual, a woodcutter now?

No rule which refers to linear order alone will work in the case of yes/no questions corresponding to complex declarative sentences that contain more than one occurrence of is (or other similar words). For forming such complex yes/no questions, a rule in the vein of 20 is required:

20 Find the occurrence of is (or similar words) that is the main verb of the sentence [i.e., the verb of its main clause], and move it to the front of the sentence.

Rule $20 \ldots$ which says the same thing as rule 3 in a different way $\ldots$ is a structure-dependent rule. It operates on expressions that are assigned a certain structure in terms of a hierarchy of 
phrases or clauses. This hierarchy in the case of $18 \mathrm{a}$ and $19 \mathrm{a}$ is partly indicated in $21 \mathrm{a}$ and $2 \mathrm{lb}$, respectively, by means of pairs of brackets around the relevant phrases.

2la [The Queen [who is dumb]] is furious.

b [The Executioner [who is demanding a pay rise]] is in jail.

The main verb of complex sentences is that verb which is not embedded within brackets in diagrams such as $2 \mathrm{la}$ and $21 \mathrm{~b}$. (The more pairs of brackets enclosing a word or phrase, the lower/deeper down it is in the hierarchy.) The structuring of $21 \mathrm{a}$ and $21 \mathrm{~b}$ makes it possible for rule 20 to find the most prominent occurrence of is (or similar other words), which this rule then moves to the front of the sentence.

Noan Chomsky has stressed the surprising nature of the fact that human language uses structure-riependent rules rather than linear or structure-independent ones. There is no logical reason why this should be the case. On his view, it would be quite easy to construct languages that use (computationally) simpler linear rules. And such languages would serve the purposes of human language -.- communication, expression of thought etc. -- perfectly well. But they would not be human languages: for children, they would be hard to leam; for adults, they would be hard to use. And so, Chomsky considers 'the principle of structure dependence' to be 'a significant, nontrivial property of human language'. 22

\subsection{Structure}

Now that we häve considered some properties of the general form of language, we next turn to a number of the basic properties of the structures on which rules such as that for forming yes/no questions are dependent. Some of these properties, we will see, are not restricted to syntactic structure, but generalize to phonological structure as well.

\subsubsection{Hierarchicality}

It is quite natural to think of a sentence as a queue of words or, more formally, a linear string of lexical items. Physically, of course, it is simply impossible to produce two or more (distinct) words simultaneously; rather, (distinct) words are uttered serially .... one after the other -..both in speech and writing. This is the rule even in dreamworlds. It is a rule which Alice did try to break once, though, when she was desperate to get some service at the window of a little shop doing duty as a post office. There we find her 
'... taking a deep breath, and speaking so quickly that the words all rushed out together …

"Idverymuchliketobuyapostagestampplease!" [TNE 147]

But these words of Alice's have not really been produced 'all at once': despite rushing out at one another's heels, they still form a queue or string.

So: in utterances, words are produced one after the other. This makes it hard to get away from the idea that; in sentences, words are interlinked by linear succession and by nothing more. And, by implication, hard to get away from the idea that sentences are word queues and nothing more. But, someone who knows about Needle's Eye World may object, there are queues and queues, a point which Alice would whole-heartedly endorse. For having plunged down the tunnel leading out of the Maze in Needle's Eye World, she landed (fortunately) not in Infinity but (less fortunately) between the Red Queen and the White Queen in the middle of a most extraordinary queue. It was, to her surprise, a queue moving in both directions (between two little shops). The Queens, however, accepted this as quite normal:

'"I daresay you've not had much experience of queues yet," was all the Red Queen would reply.

"Where I come from," Alice ventured to say, "they only move in one direction."

"What a waste of a good queue!", said the Red Queen.

"That'd be like a stairway that only went up, not down." [TNE 140]

A two-way queue may well be able to move in opposite directions. But in terms of make-up, it is just another queue, consisting of members linked in no other way than simple left to right succession (or right to left succession). And in this respect, sentences are essentially different. To get a macroscopic view of how sentences are made up, we have to look, then, at the ways in which sentences are not just strings of words hanging together like the links of a chain (or the members of a queue). This immediately places on our agenda, believe it or not, the topic of trees.

Trees are rather special ingredients of the dreamworlds visited by Alice. For instance, the place from which the Cheshire Cat grins down on Wonderlanders is, as you know, a tree. And if you wonder who in Looking-Glass Country takes care of the talking flowers, you may be surprised to hear that it is a tree, one that knows what to do when danger threatens: 
"It could bark", said the Rose.

"It says Bough-wough!" cried a Daisy.

"That's why its branches are called boughs!" [TLG 202]

Trees of a special species are similarly important ingredients of the world of language: in terms of their make-up, or structure, sentences are trees. To see what this means, consider the following sentence (or, more precisely, the sentence underlying the following utterance):

22. The barking tree frightens the Cheshire Cat.

This sentence is made up of two big phrases: the Noun Phrase (NP) the barking tree and the Verb Phrase.(VP) frightens the Cheshire Cat. That fact can be represented schematically with the aid of what is called a tree (diagram).

23

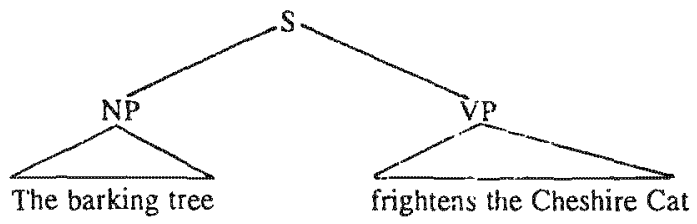

(In a tree diagram, a triangle means that the internal make-up of the phrase does not matter for the point(s) under discussion.)

The Noun Phrase the barking tree is in turn composed of the Determiner (Det) the, the Adjective (A) barking and the Noun (N) tree. And the Verb Phrase frighters the Cheshire Cat is constructed out of the Verb (V) frightens and the Noun Phrase the Cheshire Cat. To represent these facts schematically also, we can extend tree (32) by adding suitable branches to it, and so forming tree 24 :

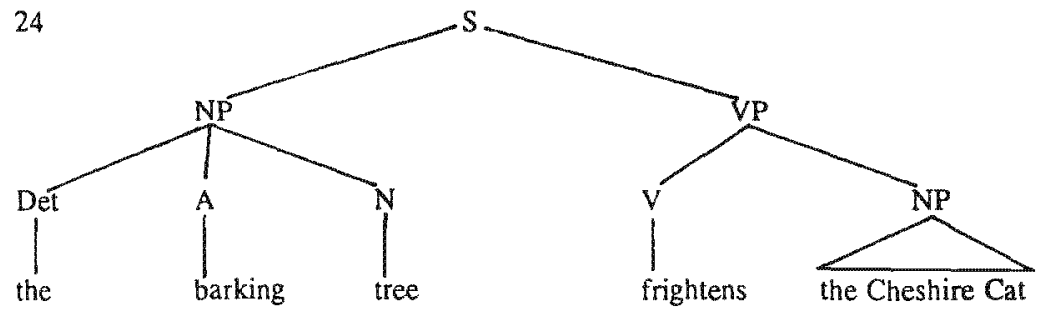


Finally the Noun Phrase the Cheshire Cat consists of the Determiner the and the Noun Cheshire Cat, which we can show schematically by adding appropriate branches to 24 , giving 25 .

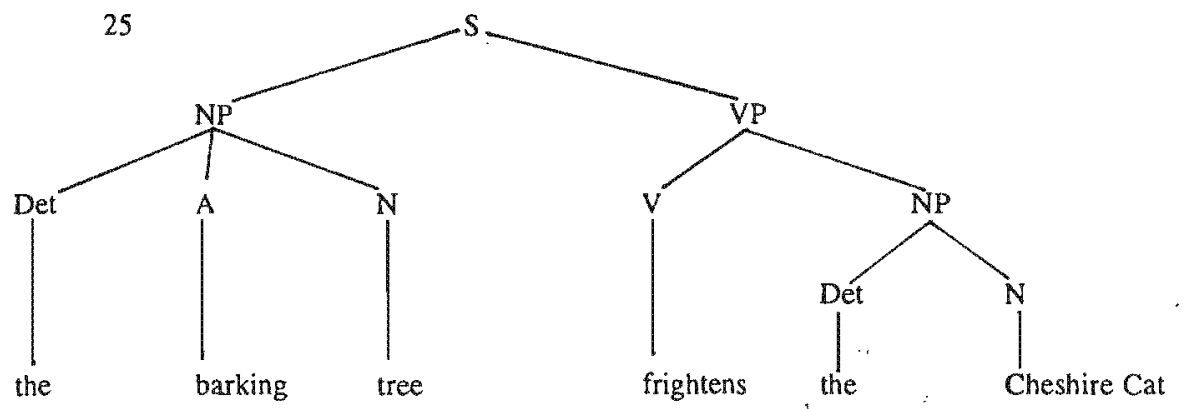

25 roughly represents what is known as the 'phrase structure' of the sentence The barking tree frightens the Cheshire Cat.

So: trees like 24 and 25 represent (aspects of) the phrase structure of sentences. What is more, such trees are built by phrase structure rules like the following:

26a A (declarative) sentence consists of a Noun Phrase followed by a Verb Phrase.

b A Verb Phrase consists of a Verb followed by an optional Noun Phrase.

c A Noun Phrase consists of an optional Determiner, followed by one or more optional Adjectives, followed by a Noun.

d The Noun can be an item such as the following: tree, Cheshire Cat, executioner, axe, gardener, Alice, .....

e The Verb can be an item such as the following: frightens, barks, beheads, .... .

The phrase structures built by such rules give information on important properties of sentences, such as the following: 
w the smallest syntactic building blocks or constituents -- the (meaningful) lexical units (roughly, the meaningful words), which hang from the lowest branches --. and the linear order (the order from left to right) in which these smallest constituents follow one another;

- the lexical categories -.- Determiner, Adjective, Noun, Verb --- to which the smallest constituents belong;

- the syntactic phrases formed by groups of words hanging together and the syntactic categories -.- Noun Phrase, Verb Phrase .... to which these phrases belong;

- the hierarchical relations that hold among the various constituents: the NP and VP directly under (i.e., dominated directly by) the $S$ are equally high in the hierarchy (i.e., of equal rank); the NP directly under the $S$ is higher in the hicrarchy than is the NP direculy under the VP, and so on.

$\therefore$ The grouping of words into phrases represents, of course, another way in which a sentence is not a simple string of words; In a simple string, every two neighbouring words are linked equally closely. A phrase structure is different in this respect: how closely any two adjacent words are interrelated depends on what phrase(s) they belong to. For example, barking and tree are closely interlinked because they are components of the same phrase. This is not so with tree and frightens: although they are adjacent, they are components of different phrases. So tree and frighens are structurally less closely interlinked than barking and tree are.

But let us get back to the idea of a 'hierarchy', which of course is a familiar one to Lewis Carroll fans. The social make-up of the dreamworlds he created is to a large extent hierarchical. At the top of the hierarchy, there are the Kings and Queens who rule over the progressively lower ranks of Duchesses, Knights, Knaves, and commoner footmen, gardners, soldiers and so on. And, like the structure of a sentence, the make-up of the House of Cards can be represented graphically with the aid of a tree diagram.

Recall that it is the nature of grammatical rules that requires us to think of sentences as tree structures rather than as simple word strings. We have seen that a rule such as the one for forming yesino questions just won't 'work' correctly unless sentences are thought of as having a structure with a vertical or hierarchical dimension as well. Specifically, this rule moves is (or similar other words) if it is the main verb of the sentence, that is to say, if is is the verb of the 
highest clause or $S$ in the hierarchy. This is illustrated graphically by tree 27 , which represents the phrase structure of sentence $18 \mathrm{a}$ ( $=$ The Queen who, is dumb, is in a purple rage).

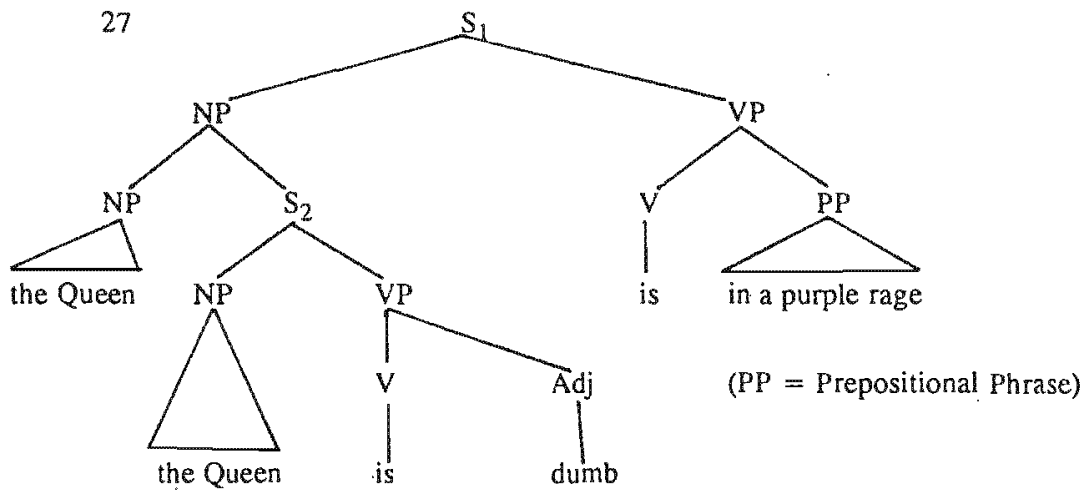

The phrase structure represented in 27 has been built with the aid of, amongst others, a recursive rule which uses one clause $\left(S_{2}\right)$ as a building block of another clause $\left(S_{1}\right)$. In both $S_{1}$ and $S_{2}$ the verb is an is of the kind that can be moved to the front by the rule forming yesino questions. This rule, however, picks out the is in $S_{1}$ for fronting since this is is the main verb of the sentence, being a constituent of the highest $S$, the matrix sentence ("mother sentence"). Though the is in $S_{2}$ is the first or leftmost is, it is ignored by the question rule because $S_{2}$ is not the highest $S$ in the hierarchy. 23

Before moving on to a second way in which sentences are not simple word strings, let's note that phrase structure is a quite economical kind of structure. That is, phrase structure uses the same limited number of phrase categories over and over in a variety of places in trees. This point is illustrated by the variety of positions in which the Noun Phrase the barking tree occurs in the following sentences:

$28 \mathrm{a}$ [The barking tree] frightens the Cheshire Cat $(=22)$

b The flowers adore [the barking tree].

c The Cat gave [the barking tree] a dismissive grin.

d The Cat sits in [the barking tree].

e [The barking tree]'s bark is worse than its bite.

f The Cat sharpens its nails on the bark of [the barking tree]. 
In 28a, the NP the barking tree occurs directly under the $S$; in $28 \mathrm{~b}$, it occurs directly under the $\mathrm{VP}$; in $28 \mathrm{c}$, it occurs directly under the VP but has a sister NP, a dismissive grin; in $28 \mathrm{~d}$, it forms part of a Prepositional Phrase along with the Preposition in; in $28 \mathrm{e}$, it forms a bigger NP along with the genitive ' $s$; in $28 \mathrm{f}$, it forms part of a bigger NP of a different kind, a possessive NP.

This example shows that a tree (or, rather, the phrase structure represented by a tree) has the property of modularity. In the words of Steven Pinker:

'... a aree is modular, like telephone jacks or garden hose couplers. A symbol like "NP" is like a connector or fitting of a certain shape. It allows one component (a phrase) to snap into any of several positions inside other components (larger phrases). Once a kind of phrase is defined by a rule and given its connector symbol, it never has to be defined again; the phrase can be plugged in anywhere there is a corresponding socket. 24

It is this plug-and-socket arrangenent that makes phrase structure such an economical kind of structure. It allows the use of the same kind of phrase in a variety of different positions in a sentence. This, in a sense, is like having a single cast of actors for the various acts in the drama that unfolds in the course of Alice's visit to Wonderland. It would be pretty wasteful, to say the least, to have one team of Wonderlanders playing in the Queen's croquet game, a completely different cast acting in the Knave's trial and so on.

\subsubsection{Discontinuity}

Simple word strings, then, lack the vertical dimension so crucial to sentence structure. The basic relation holding between the words in such a string is that of being next to one another -.. rubbing shoulders as it were ... or, to put it in terms more agreeable to the Dodo, that of adjacency. In the preceding paragraph, however, we have already seen that two words may be neighbours in a sentence without being closely related. (Which is a bit like Alice and the Hatter sitting next to each other at the Mad Teaparty without being related in any deeper way.) The absence of a deeper relation holding between two adjacent words is, of course, a consequence of the fact that the words in a sentence form groups or phrases. But what would this mean with regard to a sentence such as The barking tree frighters the Cheshire Cat? As is clear from tree diagran 25, the adjacent words barking and tree are closely interlinked in the sense that they are constituents of the same phrase, a Noun Phrase. In the case of tree and frightens, however, things are different. Though adjacent, tree and frightens are constituents of different phrases, a 
Noun Phrase and a Verb Phrase respectively. So, from a structural point of view, tree and frightens hang together less closely than barking and tree do. This is evident from the fact that, unlike tree and frightens, barking and tree are not separated from each other by rules that form sentences such as The Cheshire Cat is frightened by the barking tree. Clearly two words can be linearily adjacent and yet have considerable structural distance between them.

The opposite is true too, however, which brings us to a further important difference between trees and simple word strings. So let us renew our acquaintance with Ping and Pang, the Siamese-Twin Cats which do everything together, including speaking. As no doubt you are able to recall, when speaking, they collaborate to utter one and the same sentence, each doing its bit in turn. For example:

'In a solemn voice, Ping said, "This tale (by yours ." " "-truly) -" said Pang, ending the modest bow begun by Ping .....

"- I have named 'The Sands of Dee' -" said Ping.

"Why that's a coincidence," said Alice loudly:

"- its heroine I have named - er, I have -" [TNE 34]

One can hardly fail to notice it: the 'stretchiness' of the ongoing utterance "This tale by yours truly - I have named 'The Sands of Dee' - and its heroine - its heroine I have named - er, I have -". Or, if you like, the utterance is cut up. It is cut up in (at least) three ways: by Ping and Pang's each in turn having a go at playing the role of speaker, by Gilbert Adair's throwing in an aside, and by Alice's ill-timed butting in. Intruding between Ping's contribution 'I have named "The Sands of Dee"' and Pang's contribution 'and its heroine ... its herione I have named - er, 1 have -', Alice's interruption causes a discontinuity in the Ping-Pang utterance. Because of this interruption of Alice's, words that should have been linked end to end have been pushed away from each other.

Discontinuity comes in various kinds. The one caused by Alice's interruption is of a relatively uninteresting kind: the interruption causing it is a factor external to the structure of the sentence, a nonlinguistic factor. Now, however, consider the discontinuities exhibited by the sentences $29 \mathrm{a}-\mathrm{d}$.

$29 \mathrm{a}$ If the Queen can have her way, then heads will roll.

b Either the Executioner gets on with the job or he gets fired.

c The Executioner will not cut the partly vanished Cat's head off.

d The Queen hates intellectual executioners and gardeners. 
These discontinuities -..- unlike the discontinuity caused by Alice's interruption -.- are of an internal, structural kind: the syntactic structure of English is such that each pair of underlined words forms part of the same discontinuous constituent, even though each pair occurs in two non-adjacent positions.

Structural discontinuity is a pervasive property of (English) sentences. A single sentence can in fact cmbody a series of interwoven discontinuities, A..A, B..B, C.C. and D..D, as is clear from 30 :
A
B
C

30 If the Queen can either get someone to cut the heads of

D

D $\quad C \quad B$

intellectual executioners and gardeners off or force

A

the King to clap them in chains, then she will be the

happiest person in Wonderland.

Simple strings of words cannot exhibit structural discontinuity. Indeed, simple strings of words are destroyed by such discontinuity. What is needed to keep the non-adjaceni parts of discontinuous constituents together is a hierarchical structure, which is something unobservable. ${ }^{25}$

\subsubsection{Long-distance dependency}

Yes/no questions are not the only kind of questions used by speakers of English. This much is clear from some of the questions fired at Alice by the Caterpillar:

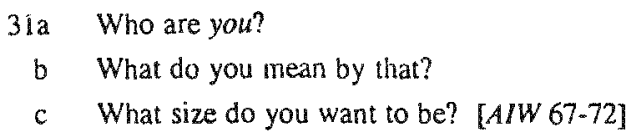

These brusque questions are examples of wh-questions. Wh-questions are sentences that, in their first position, have either some wh-word such as who (whom, whose, what, when and so on) or some wh-expression such as what size. In understanding these questions of the Caterpillar's correctly, Alice has really done rather well. For example, in the Caterpillar's 
question What do you mean by that?, what occurs in the first position of the sentence. But Alice has to interpret this question as if what occurred after the verb mean, as in You mean WHAT by that? (This last, incidentally, isn't a yesino question either.)

That certain words or expressions have to be interpreted 'out-of-place' illustrates another important way in which sentences are not simple word strings. But how is this kind of interpretation possible? Let us tackle this question by considering 32-34:

32a What did the Queen give to the Executioner?

b The Queen gave a double-edged axe to the Executioner.

$33 \mathrm{a}$ Whom did the Kirave sell the Queen's tarts to?

b The Knave sold the Queen's tarts to the Hatter.

$34 \mathrm{a}$ When did the Queen make the stolen tarts?

b The Queen made the stolen tarts on a summer's day.

In each of these, the a sentence is a wh-question and the b sentence is a possible answer to that wh-question.

The above wh-questions are interesting in regard to meaning: though the wh-word occurs in the first position of the sentence, it is understood as if it occurred much later or further down in the sentence. Concretely, in $32 \mathrm{a}$, what is understood as the direct object following the verb gave (more on the systematic relationship between gave and did ... give presently). In $32 \mathrm{a}$, that is, what is understood in the same way as a double-edged axe in sentence $32 \mathrm{~b}$. Similarly, in $33 a$, whom occurs in the first position of the sentence but is understood as the indirect object of the verb, that is as the Noun Phrase occurring in the final position of the sentence. This is to say that in 33a, whom is understood in the same way as to the Hatter in 33b. And in 34a, When is understood as a prepositional object, like on a summer's day in 33b.

But how could a wh-word occurring in the first position of a sentence be understood as a constituent following much later in a sentence? Note, to begin with, that there is a type of question, so-called echo questions, in which wh-words do actually occur in the position in which they are understood to occur. To see this, consider the echo questions $35 \mathrm{a}-\mathrm{c}$, which correspond to the wh-questions $32 \mathrm{a}, 33 \mathrm{a}$ and $34 \mathrm{a}$, respectively: 
35a The Queen gave WHAT to the Executioner?

b The Knave sold the Qucen's tarts to WHO(M)?

c The Queen made the stolen tarts WHEN?

Echo questions such as $35 \mathrm{a}-\mathrm{c}$ are normally used by a second speaker to express disbelief, amazement and so on about something that has just been said by a first speaker. This second speaker, repeating all or part of what the first speaker has said, uses a heavily stressed $w h$-word in place of the constituent whose meaning is the source of his/her disbelief or amazement. 26

If sentences were simple word strings, echo questions would represent the expected case: words or expressions are interpreted in the position in which they physically appear. Whquestions, by contrast, would represent the unexpected case: words or expressions are interpreted 'out of position'. As is pointed out by Noam Chomsky, however, it is common for expressions to be interpreted in a position different from the one in which they physically appear. in fact, Chomsky considers this kind of ('out-of-place') interpretation to be so pervasive and widespread a property of natural language that every theory of language has to 'capture' it somehow. 27

From this phenomenon of 'oui-of-place' interpretation, what do we learn about the structure of sentences? What we learn is this, to put it non-technically: phrases that are physically far apart can have a link between them which users of the language know about even though the link cannot be seen or heard. Technically, this is known as (a relationship of) long-distance dependency. For example, to be able to explain how what can be understood as the direct object of give in the wh-question $31 \mathrm{la}$, the linguist may assume that there is an inaudible or invisible link between what and the socket in which the Noun Phrase understood as the direct object occurs. The linguist may assume, that is, that between what and this direct object NP, there exists some long-distance dependency.

And just how far, you may well wonder, would a long-distance dependency be able to stretch? Quite a distance in linguistic terms, as the wh-question 35a shows when it is compared with the echo-question $36 \mathrm{~b}$.

36a What does the Hatter say that the Queen thinks that the demoted Executioner should use for cutting down the barking tree?

b The Hatter says that the Queen thinks that the demoted Executioner should use WHAT for cutting down the barking tree? 
Long-distance dependency is clearly a quite elastic sort of relation in that it can stretch over various phrases or clauses. In this, it reminds one of the extendable tail shared by Ping and Pang: this tail (inter)linked the two of them, and it could stretch at least twenty paces. Yes, it even allowed them to fight a duel with pistols, as witnessed by Alice:

'Alice watched the two Cats take up their positions back-to-back, with their tail curling up in the middle like a huge question-mark, and two very rusty old pistols clutched in their paws. ' [TNE 37-38]

And:

'Though she felt she ought to urge them against fighting, Alice was simply too curious to know how Siamese-Twin Cats, attached at the tail, could possibly manage to march twenty paces away from each other. So she solemnly counted "One - two - three - four -": and as their tail gradually straightened out, then stiffened all over, she became more curious than ever. ' [TNE 38]

Since their marching was abruptly ended by a thunder storm, Alice never found out just how elastic Ping and Pang's joint tail was. (Actually, despite the eighteen lives they had between the two of them, they had been hoping to be able to get a thousand paces away from each other for the pistol duel.)

Not having to contend with the disruptive intervention of events such as thunder storms, linguists have been able to learn quite a lot about the constraints on long-distance dependencies. Significantly, they have discovered that all long-distance dependencies in all languages are restricted by similar 'super-rules' or universal constraints. By analyzing sentences such as $37 \mathrm{a}$ $f$, they have found out that long-distance dependencies cannot just stretch from any place in a sentence to just any other place in a sentence (in the following sentences $t$ indicates the second position or terminal to which the dependency stretches, the first position being that in which the wh-word occurs).

37a *Whom did the Knight believe the King thought that the Hatter told the March Hare that the Queen would order the Executioner to behead $t$ on the croquetground?

b What did the Executioner wear a top hat and $t$ for carrying out his duties?

c *Which Queen was the croquet game played on the day that $t$ fired the intellectual Executioner? 
* What is for the Executioner to get / easy?

e Which axe did the Queen hire a new Executioner who uses $\imath$ ?

f What did Alice wonder who would get $l ?^{28}$

The wh-question $37 \mathrm{a}$ is an extremely complex sentence: it has no fewer than four (or even five) clauses, with the long-distance dependency stretching all the way from the first to the last. So one could say that this wh-question was awkward because the dependency was being 'overstretched'. In the case of $37 \mathrm{~b}$ - $\mathfrak{f}$, however, it is a different story: these sentences are far less complex. This means that their ungrammaticality is caused, not by their "length" or rather degree of complexity, but by other aspects of their structure. The wh-word/expression has been moved out of a coordinate structure ... [a top hat and $t] \ldots$ in the case of 37b; out of a sentential complement to a Noun --- [that $t$ fired the intellectual Executioner] -.- in 37c; out of sentential subject - - [for the executioner to get 1 ] $\cdots$ in 37 d; out of a relative clause.-- [who uses $[$ ] -... in 37e; and out of an indirect question -... [who would get $t$ ] -.- in 31f. Languages are subject to 'super-rules' or universal constraints which forbid moving a wh-word/expression out of these structures (or, alternatively, which say that long distance dependencies cannot stretch from a wh-word/expression at the beginning of a sentence to the position occupied by t). ${ }^{29}$ But, to close this paragraph, let us repeat its two main points. Firstly, sentences are able to incorporate long-distance dependencies. Secondly, this ability of sentences makes them essentially unlike (simple) word strings. In a (simple) word string, after all, the words merely interlink neighbour-to-neighbour, like the links of a chain.

\subsubsection{Transformation}

'Out-of-place' interpretation and long-distance dependency, we have seen, are two sides of the same phenomenon. And we have noted that Noam Chomsky considers 'out-of-place' interpretation to be such a pervasive and widespread property of natural language that every theory of language has to 'capture' it. Chomsky's theory of language does this in a way that makes sentences even less like simple word chains --- which is the point we will be pursuing in this paragraph.

Here is the essence of Chomsky's proposal: in the case of a phrase that is interpreted "out-ofplace", there exists a relation of transformation between the phrase in the position where it is interpreted and the position where it physically appears. Specifically, he argues, there is an operation that (in some sense) moves the expression from the place of its physical occurrence to the place of its interpretation. In this latter position, moreover, this operation, called a (syntactic) transformation, leaves an inaudible and invisible copy of the moved phrase. This 
copy is called a trace, represented by the symbol $t$. What this involves in a concrete case, that of the wh question $32 \mathrm{a}$, is roughly shown in 38 .

38 What did the Queen give t to the Executioner?

$\uparrow$ wh-movement

In 38, wit-movement represents the operation or transformation that moves what out of the direct object position -...- where a trace $t$ is left behind -..- to the front of the sentence. ${ }^{30}$

But 38 oversimplifies the matter in an important way, one that can be illustrated with the aid of the 'removement transformation' routinely carried out by the Executioner in the line of his duties. This operation -... beheading .... involves two states, a 'before' or input state and an 'after' or output state. In the 'before' state, the victim's head is in its original position; in the 'after' state, its head is in a '(re)moved' position. And if one wished to make a drawing of someone in these two states, a single picture would not be able to do the job. Two would be required: one of the 'before' state and one of the 'after' state.

Much of this carries over to syntactic (movement) transformations. Contrary to what 38 suggests, the movement operation in question involves two states: a 'before' or input state and an 'after' or output state. In the 'before' state what is in the direct object position; in the 'after' state, however, it is in the position at the front of the sentence. And these two states cannot be described with the aid of a single tree diagram. Two are required: one, such as $39 \mathrm{a}$, to represent the 'before' state, and another, such as $39 \mathrm{~b}$, to represent the 'after' state.

$39 \mathrm{a}$

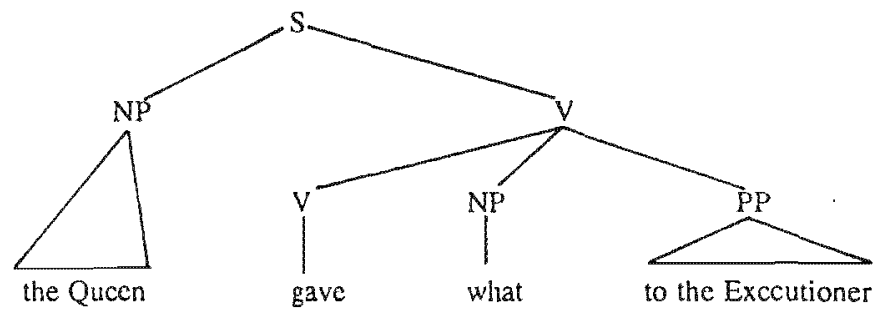


b

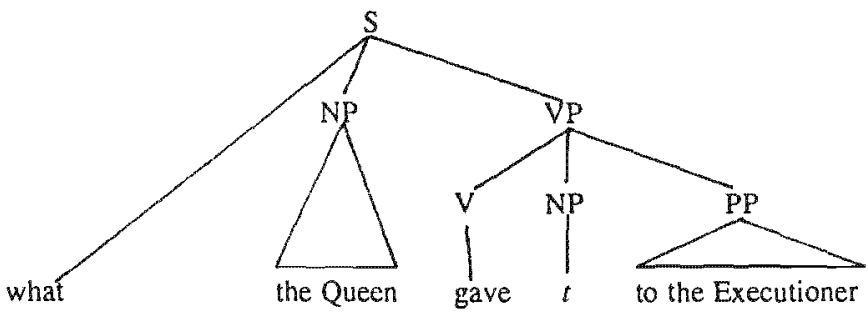

(39b has to undergo a further operation to replace gave by did ... give. We need not here, however, concern ourselves with this operation. Nor do we need to go into the nature of the socket that what is moved to or into the nature of the branch linking this socket to $S$.)

The important point illustrated by $39 \mathrm{a}$ and $\mathrm{b}$ is that the structure of wh-questions cannot be characterized with the aid of a single phrase structure tree alone. Two are required. The first -- exemplified by 39 a -... represents what Noam Chomsky has called the underlying or deep structure of in wh-question. The second tree $\ldots$ exemplified by $39 b \ldots$-... represents the superficial or surface struciure of a wh-question. This means that wh-questions have a (different) structure at (each of) two syntactic levels. This idea has, moreover, been generalized by Chomsky to all sentences. In other words, every sentence has at least rwo, differing, syntactic structures: an underlying or deep structure (tree) and a superficial or surface structure (tree). The deep structure (tree) of a sentence is built by phrase structure rules. One or more sytatactic transformations (or transformational rules) each move some phrase of the deep structure (tree) to form the surface structure (tree) of the sentence. A scientific description of a language which uses not only phrase structure rules but also transformational rules is called a transformational grammar. 31

This brings us to two more ways in which sentences are not simple word strings -.. that is, if Chomsky's theory of transformational grammar is correct. First, a simple word string is a single-storey string. In having both a deep and a surface structure, a sentence is by contrast a double-storey structure. Second, in a word string every link/word has to be physically there. A word string cannot contain 'missing' links/words. If a link/word is removed, the string is destroyed. Sentences, we have seen, are different in this regard too. A word like what can be moved out of its original position, without the sentence collapsing into a jumble of unconnected words. The 'vacated' position, as we have seen, is filled by a trace: a non-physical item that has been aptly characterized as 'a sort of unproduced pronoun'. Although traces are unpronounced (by speakers), listeners detect them when they process sentences and use them unconsciously in interpreting the wh-words/expressions in whose position the traces have been 
left behind. Traces assist listeners in understanding sentences by reminding them of the role - direct object, indirect object and so on -..- that the moved phrases are playing. 32

Traces, then, resemble the grin of the Cheshire Cat in a way:

"All right," said the Cat; and this time it vanished quite slowly, beginning with the end of the tail, and ending with the grin, which remained some time after the rest of it had gone.' [AIW 90]

As the Cat's grin marks the place from where it has disappeared, so traces mark the position from which wh-words have been moved. But traces are less curious things than the Cat's grin. Or at least would be to Alice, who thought:

"Well! I've often seen a cat without a grin ... but a grin without a cat! It's the most
curious thing I ever saw in all my life!."' [AIW 90$]$

In Wonderland, grins could clearly be cut loose from 'grinners' to lead a life of their own. In sentences, however, there remains an invisible and inaudible link between a trace and the word or phrase whose trace it is. Otherwise people simply would not be able to interpret whquestions such as those considered above. It is this link, then, that makes it possible for Alice to correctly understand the Caterpillar's 'Who are you?', 'What do you mean by that?' and other wh-questions.

In sum: sentences differ in important ways from simple strings of words that are connected like links in a chain: (i) sentences are structured in a vertical or hierarchical dimension too; (ii) words are grouped in phrases, with the result that adjacent words may be structurally far apart; (iii) sentences exhibit discontinuities, with the result that non-adjacent'words may be structurally closely linked; (iv) sentences contain long-distance dependencies, allowing words or phrases to be interpreted 'out-of-place'; (v) sentences have two levels of phrase structure; (vi) sentences can have building blocks that are not audible or visible. The vast majority of linguists will agree that sentences exhibit properties (i) - (iv). But about the status of (v) and (vi) linguists have disagreed amongst themselves in a way that makes one think of the battle fought by the Letters of the Alphabet in Needle's Eye World:

'First into the fray were the A's and the V's. They lunged out at each other, pointed edges to the fore, reminding Alice of some pictures she had chanced to see in one of their cousin's books, of Knights jousting in medieval tournaments. Then the K's started 
to snap at everything in sight with their sharp little jaws. The P's propelled themselves across the room like cannonballs, making a strange humming noise as they flew by. And the E's and I's combined forces by changing into tridents and puncturing all those letters, like the C's and G's and U's, whose soft curves made them vulnerable to their attack.' [TNE 179-180]

The battle about the existence of a level of deep structure, of transformational rules and of the traces left by such rules has of course been fought by supporters and opponents of Noam Chonsky. Recently, however, things have taken an interesting turn, with Chomsky himself exploring the possibility of eliminating both the level of deep and the level of surface structure. In his recent view, it is not conceptually necessary to attribute these levels of representation to language. ${ }^{33}$ For Chomsky to take this new stance is on a par with Alice's telling the Letters of the Alphabet that what they have been fighting about is a non-issue. (According to Lord $X$, though, there was a real issue: "Why ... must such fine, upstanding letters of the Alphabet as $V, W, X, Y$ and $Z \ldots$ always suffer because of our position in the scheme of things? Why ... must we always come last?" "[TNE 175-176])

\subsubsection{Pervasiveness of structuring}

Certain properties that distinguish a sentence from a simple word string are not restricted to syntactic structure. Interestingly, they characterize phonological structure too, which means that they are pervasive properties of language. We approach these properties by having a second look at the sentence which Alice had to utter so rapidly in order to get some service at the little shop selling stamps. Gilbert Adair, you may recall, represents this sentence as follows:

39 Idverymuchliketobuyapostagestampplease!

Now, 39 may suggest that a sentence or a word is a simple string of speech sounds at the level of phonology. This idea, however, would be wrong. Why?

Consider the word argumenation (it denotes a form of interaction at which Humpty, Alice and the Caterpillar excelled). Phonologically, this word is not a simple sequence of speech sounds represented (by the various letters) in 40 . 
Phonologically, argumentaion, rather, has the structure represented in 41 .

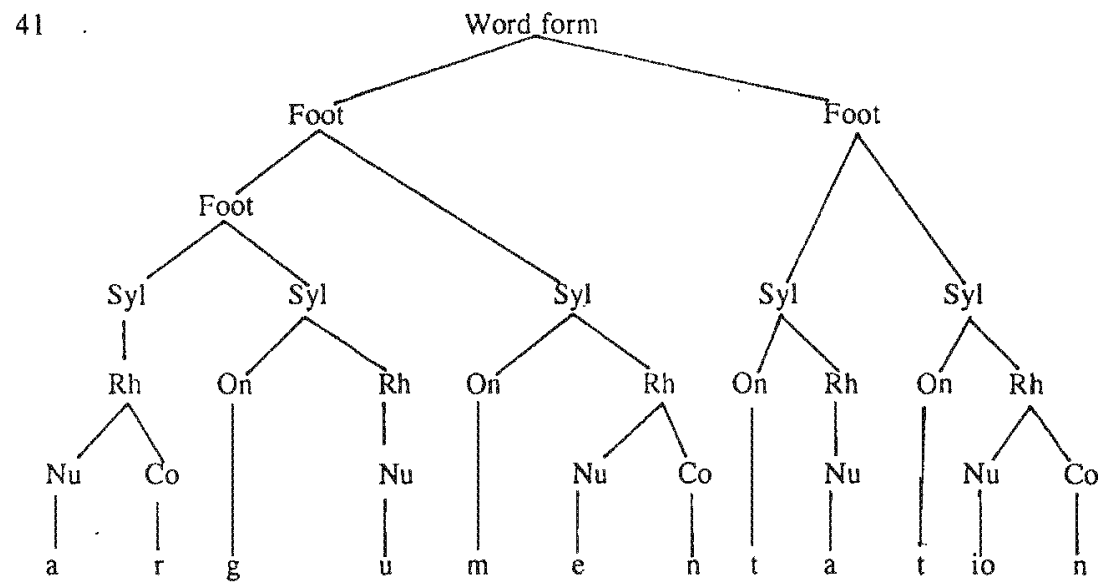

Diagram 41 makes it clear that, like the syntactic structure of a sentence, the phonological structure of a word has the shape of a two-dimensional tree. More concretely, words are made up phonologically in the following way:

- Speech sounds are pronounced in groups known as syllables (represented by 'Syl' in 41) which have two components: an optional onset ('On' in 41) and an obligatory rhyme (' $\mathrm{Rh}^{\prime}$ in 41) which, in turn, is made up of an obligatory nucleus (' $\mathrm{Nu}$ ' in 41 ) and an optional coda (' $\mathrm{Co}$ ' in 41).

- A sequence of syllables consisting of a stressed syllable followed by one or more unstressed syllables is grouped into rhythmic units known as feet:

Feet combine to make up word rorms.

The phonological structure of words, in a nutshell, has the form of a hierarchy in which smaller units are grouped at various levels or tiers into larger units. In short: hierarchies, groups and levels characterize the organization of both syntactic structure and phonological structure. 34 


\subsection{Use}

From the point of view of function, so we have seen, language is a means or procedure of converting messages into utterances and vice versa. And we have found language to be quite productive as a means of doing this: in principle, there is no human thought or message that cannot be converted with the aid of language into an acceptable utterance and vice versa. This productivity of language might tempt one to conclude that the form of language will in the most fundamental respects be determined by function or use. But such a conclusion would be mistaken, which is the point we will be taking up below.

\subsubsection{Autonomy}

Lewis Carroll accommodates his dreamworld creatures in a variety of amazing houses. In Wonderland alone, there is the house with the hall that Alice could get out of through a fifteeninch-high door only, the little house (only about four feet high) whose front door is watched over by a piscine footman, the house whose door is in a tree, and, of course, the March Hare's house:

'... she [i.e., Alice] thought it must be the right house, because the chimneys were shaped like ears and the roof was thatched with fur.' [AIW 91]

Out of this funny house, one feels, Lewis Carroll could have gained a lot more dreamworld mileage. Particularly from the ear-shaped chimneys. Ears, of course, have a function: they are there for hearing, especially if they are as large as a hare's. But, for some reason, Lewis Carroll missed out on the opportunity of making the March Hare's house one that could hear and talk. A hearing and talking house would have been something really special. Just think of all the amazing things that such a house would be able to do: from eavesdropping to stonewalling! The ear-shaped chimneys of the March Hare's house are not, however, functionally well motivated features of the place. Their one and only function, in fact, is to identify ('(ear)mark') the house as the March Hare's, a point that we will return to below.

Language has formal features that remind one of these ear-shaped chimneys, features lacking functional motivation. And some are of a quite significant sort. Such as structure-dependency. You will recall that, on Chomsky's view, structure-dependent rules are computationally more complex than structure-independent ones. And that Chomsky thinks a language using simpler rules --- simpler by virtue of being structure-independent or linear --. would be quite easy to construct. Significantly, Chomsky moreover thinks that: 
'This language would function perfectly well for purposes of communication, expression of thought, or other uses of language."

This means that, for Chomsky, the structure-dependency of language is not required by, and consequently is unmotivated in terms of, the functions and uses of language. But he nevertheless assigns structure-dependency the status of 'a significant, nontrivial property of human language'. No animal language is characterized by structure-dependency. This means that structure-dependency plays the same role as the ear-shaped chimneys or the fur roof of the March Hare's house, that of discrimination. It sets language apart from other, non-human systems of communication, expression and so on.

Structure-dependency, you will recall, is a property of the general form of language. But this is not the reason why it lacks motivation in terms of the functions or uses of language. The shape of specific building blocks of language -.. or 'structural components' of language as the Dodo would have insisted on calling them .... is similarly unmotivated from the point of view of function. As a case in point, take the rule for forming wh-questions. As regards form, it is a movement rule. But the meaning or use of wh-questions does not require a rule that performs a movement operation. Wh-questions would express their meaning, or perform their function, equally well if they were formally constructed in a completely different way. Like having (a normally stressed) wh-word or expression in the position of the questioned constituent. (A whquestion formed in this way would differ from a corresponding echo question in regard to the degree of emphasis placed on the wh-word/expression only. As a matter of fact, some languages form their wh-questions in just this way. In Korean, for example, the wh-question corresponding to Which college do you think that Chelsoo went to? is the literal equivalent of You Chelsoo which college went think?, with the wh-expression which college appearing (unmoved) in the middle of the question.

As regards the direction of the movement carried out by the rule of wh-movement, one could equally well have a rule of wh-movement that moved the wh-word/expression to the end rather than to the beginning of the sentence. Which is to say that the direction of the movement is not required by the function or use of the rule. Similar observations may be made regarding the rule for forming yes/no questions, another rule whose function in no way requires it to be a movement rule. 35

What has been said above about structure-dependency and about the two rules of question formation applies to much of the general form of language and the form of the specific 
structures used by it. Here is the essence of the matter: linguistic form is generally autonomous from function or use. Function or use and linguistic form are in general linked in an arbitrary way, as we have seen above in connection with individual words too. ${ }^{36}$ To understand the qualification 'in general', let us return to the March Hare's house, with its ear" shaped chimneys and fur roof. This house would have been a lot queerer, had it belonged to someone else, to the Hatter for instance. Why? In a way, it is natural for a March Hare to live in a house with chimneys shaped like ears and a roof thatched with fur. These features of the house resemble certain features of the Hare. That is, certain features of the house and certain features of its occupant are linked by a relation of iconicity. This relation, of course, does not link the March Hare's house to the Hatter. A hat-shaped house would have been a more natural kind of dwelling for the Hatter.

In restricted areas, linguistic form and meaning are likewise said to resemble each other or to be linked to each other in terms of iconicity. For example, in certain kinds of expressions, form and meaning resemble each other in a quantitative way: an increase in form corresponds with an increase of what is referred to via meaning. The reduplicative constructions or reduplications used by certain languages are a case in point. For example:

A verb is reduplicated to express repeated or continued action. In Tzeltal, -pik means 'to touch it lightly'; -pikpik means 'to touch it lightly repeatedly'.

- A noun is reduplicated to express increased number or quantity. In Mandarin, ren means 'man'; renren means 'everybody'.

- An adjective is reduplicated to express greater intensity of a quality. In Thai, dii means 'to be good"; didii means 'to be extremely good".

In English, too, more form can signify more of what is meant. This is illustrated by the following sentences:

40a The cruel Queen has a passion for beheadings.

b The cruel, cruel Queen has a passion for beheadings.

c The cruel, cruel, cruel Queen has a passion for beheadings.

The expressions cruel, cruel in $40 \mathrm{~b}$ and cruel, cruel, cruel in $40 \mathrm{c}$ are lexical repetitions: each repetition of crucl represents an increase in form which corresponds with an increase (or intensification) in what is meant. 
The link between form and meaning in reduplications or repetitions is undeniably of a less arbitrary, more natural sort. But what we have here is an extremely general, hence quite weak, kind of iconicity. An increase in form may mean an increase not in one particular dimension only, but in various dimensions, including action, number, quality and so on. What is more, the meanings 'continued or repeated action', 'increased number or quantity' and 'greater intensity in quality' can be expressed by other linguistic means than the reduplication or repetition of a form. That is, these meanings are not linked in terms of necessity to forms created by means of reduplication. The meaning 'increased number', for example, can be expressed in a functionally arbitrary way by means of a numeral (two, sen, many, etc.), an affix $(-s,-e n)$, a syntactic phrase (more than one) and so on. Using any of these linguistic means in order to convey that meaning is like having a brass plate with the inscription 'March Hare' on its front door to identify the Hare's house. Iconic features such as ear-shaped chimneys and a fur roof are not necessary means for identifying houses either. ${ }^{37}$

\subsubsection{Unusability}

Ear-shaped chimneys will in all likelihood make for a pretty poor sort of chimney, unable to suck out smoke effectively. After all, such chimneys have not been designed for performing this function. Likewise, a fur roof may be rather useless when it comes to keeping a house dry. In general, it might seem, things whose form was not functionally fully motivated should be expected to be highly usable. Is this so with language?

As far as productivity is concerned, we have found language to be a good instrument for converting messages into utterances and vice versa. But from other functional perspectives, language is 'unusable to a considerable degree' or 'badly adapted to use', according to Noam Chomsky. On the one hand, many expressions provided by our language cannot be easily 'handled' by what he calls our 'performance systems', that is by our speech production and speech comprehension systems. And it is not only highly complex sentences such as 4 la that are hard to process; seemingly short and simple ones such as $41 \mathrm{~b}$ and $\mathrm{c}$ are, too:

4 a Never imagine yourself not to be other-wise-than what might appear to others that what you were or might have been was not otherwise than what you had been would have appeared to than to be otherwise. [AIW 122]

b The Queen hit the hedgehog hit it.

c Alice did not want the Cat not to promise not to vanish again. 
You may recall that 41 a was spoken to Alice by the Duchess, who went on to rephrase it as $B e$ what you would seem to be in order to make it more understandable to the struggling Alice. $41 \mathrm{~b}$, in turn, is a reduced form of the more easily processible The Queen who was hit the hedgehog hit the (same) hedgehog. $4 \mathrm{lc}$ is hard to process because of the complex way in which the three nots are interlinked. Clearly, language provides for a vast number of sentences that are very hard, if not impossible, to use.

On the other hand, Chonsky points out that unusability cuts across deviance. Some deviant or ungrammatical expressions are perfectly understandable, hence usable. This is illustrated by such utterances as those produced by the Diamonds, whom we met in par. 3.3.2 above:

$42 \mathrm{a}$ *It's a quarrelling gardeners, they are.

b * The Cook remembered when she hurts herself the other day.

c *The Gardeners pain: four rose.

Conversely, there are non-deviant sentences that are quite hard to understand. Many grammatical sentences pose conceptual difficulties that speaker-hearers cannot process in their stride. To convince yourself of this, do have a go at interpreting the following sentences (which are about (the name of) a melancholy song sung by the White Knight):

$43 \mathrm{a}$ Though the name of the song is called Haddocks' Eyes, the song's name really is The Aged Aged Man.

b Though the song's name really is The Aged Aged Man, the song is called Ways and Means.

c Though the song is called Ways and Means, the song really is A-sitting on $A$ Gate.

d Though the song is called Ways and Means, the name of the song is called Haddocks' Eyes.

Perhaps, like Alice, you may find these sentences hard to understand, even though none of them are ungrammatical. Nor do any of them pose perceptual problems of the kind that arise in the processing of sentences $42 \mathrm{a}-\mathrm{c}$.

Why, then, are sentences $43 \mathrm{a}-\mathrm{d}$ so hard to interpret? The problem, you may think, is one of contradiction. Considered individually, each seems to contain an internal contradiction. And considered collectively, they seem to contradict each other. The actual problem, however, is 
not one of contradiction, a point which emerges from the following conversation between Alice and The White Knight:

"The name of the song is called Haddocks' Eyes" [said the Knight]

"Oh, that's the name of the song, is it?" Alice said, trying to feel interested.

"No, you don't understand," the Knight said, looking a little vexed.

"That's what the name is called. The name really is 'The Aged Aged Man."

"Then I ought to have said "That's what the song is called"?" Alice corrected herself.

"No, you oughtn't: that's quite another thing! The song is called 'Ways And Means': but that's only what it's called, you know!"

"Well, what is the song, then?" said Alice, who was by this time completely bewildered.

"I was coming to that," the Knight said. "The song really is 'A-sitting On A Gate': and the ture's my own invention." [TLG 306]

From this intriguing interchange, it is clear that the sentences $43 a-d$ are contradictory neither individually nor as a group. Rather, understanding them is hard because of the way they tax our conceptual system. Specifically, to be able to understand them, we have to draw a series of rather fine conceptual distinctions, including the following three:

- the name of the song vs. the song itself;

what the name is vs. what the name is called;

what the song is vs. what the song is called.

If these distinctions are 'kept in mind', the meaning of sentences in $43 a-d$ can be worked out. But there lies the rub. 'Keeping these distinctions in mind' requires extremely hard conceptual labour. Which is to say that sentences $43 \mathrm{a}-\mathrm{d}$, though grammatical, fall short of being usable.

Had language been designed so as to be highly usable, we would not have the crossclassification illustrated above: deviant sentences would be relatively hard to understand, hence relatively unusable. And nondeviant sentences would be relatively easy to understand, hence usable. Chomsky, incidentally, does not consider the unusability of language to interfere with linguistic communication. Speakers and hearers have similar languages and performance systems. So it is generally the case that, what speakers can say, hearers can understand. 38

To sum up, we need to note two contrasting points. On the one hand, language is strikingly productive in having the potential to match any message or thought which someone can 
conceptualize with an acceptable utterance and vice versa. On the other hand, language is not fully usable in that its productive potential provides for many pairings of messages and wterances that the performance and conceptual/cognitive systems of speaker-hearers cannot readily process.

\subsection{Substance}

Whilst pausing for refreshments in the course of their fight, the lion and the Unicorn met Alice where she was having a conversation with the King and his Messengers. Both fighters were more than a bit puzzled about what Alice was:

"What's this!" [the Lion] said blinking lazily at Alice, and speaking in a deep hollow tone that sounded like the tolling of a great bell.

"Ah, what is it, now?" the Unicorn cried eagerly. "You'll never guess! I couldn't."

The Lion iooked at Alice wearily. "Are you animal - or vegetable - or mineral?" he said, yawning after every other word.' [TLG 289]

The Lion's second question illustrates another one of the dimensions that one has to take into account when trying to come to grips with the nature of something: the dimension of substance (or stuff). Below, then, we will be concerned with the question 'What is the substance of (a) language?' (We won't find it --. I can assure you - - to be animal, vegetable or mineral! Nor 'fabulous monster', a fourth possibility suggested by the Unicorn with reference to Alice.)

The ingredients of the world of language that we have examined so far vary in regard to substance. Some of these linguistic entities are physical ones: the signals of spoken utterances, for example, are phonic in substance. Others we have found to be mental ones: the various language capacities form part of the human mind. Still others are compound in regard to substance: the intentional acts making up language behaviour are complex in having both a mental side (made up of the stuff of intentions) and a physical side (made up of the stuff of actions). In short, the world of language draws its substances from various ontological domains, including the physical and the mental.

But what is the substance of (a) language itself? Many scholars will consider this to be an open question. The divergent answers suggested to it are too complex to survey and appraise here. Since much of the recent discussion has been stimulated by Noam Chomsky's thinking, lef's consider this in outline. 39 
Chomsky's position on the nature of (a) language includes two basic ideas that bear directly on the question about the substance of language. On the one hand, he considers language to be something mental. He arrives at this position by identifying language with knowledge of language, which he takes to be a cognitive system represented in the mind. More specifically, as we saw in par. 3.2.3, a speaker-hearer's knowledge of a particular language is considered by Chomsky to be an attained state of a certain mental faculty: the language faculty. This means that Chomsky considers a particular language such as English to be something mental in regard to substance. The same goes for language in general. In par. 3.3, we saw that what is loosely called 'language in general' is taken by Chomsky to be somehow embodied in the language acquisition capacity. In his thinking, this capacity is simply the initial state of the language faculty.

On the other hand, Chonsky considers the possibility of language being something abstract. In particular, he explores the idea that language is an abstract object, the object of knowledge of language. As an abstract object (a) language, for Chomsky, is an image of the generative procedure represented in the mind. By means of the term 'abstract', Chomsky wishes to indicate that a particular language is abstracted (or 'drawn off') from the attained state of the language faculty, whilst language in general is abstracted from the initial state of this faculty. It is, however, unclear to Chomsky whether the step of abstracting (a) language, from a state of the language faculty is motivated. His doubts spring from his assumption that the properties of (a) language are determined completely by those of the relevant state of the language faculty. For Chomsky, accordingly, (an) abstract(ed) language is not characterized by any properties or principles that do not also characterize the mental state that it has been abstracted from. 40

But suppose that (a) language were an abstract object. What could its substance then be? What is the nature of the stuff denoted by 'abstract(ness)'? Obviously it cannot be nothingness, the nature of which Alice contemplated with some alarm when suffering yet another bout of severe shrinking:

'First, however, she waited for a few minutes to see if she was going to shrink any further: she felt a little nervous about his; "for it might end, you know," said Alice to herself, "in my going out altogehter, like a candle. I wonder what I should be like then?" And she tried to fancy what the flame of a candle looks like after the candle is blown out, for she could not remember ever having seen such a thing. ' [AIW 32] 
Nor does 'abstract(ness)' in the sense used by Chomsky denote the substance of objects that are abstract in a Platonic sense. Such objects ... including ideas such as 'The Good', 'The Beautiful' and 'The Just' -... are taken to be neither physical nor mental. They are spaceless; they are placeless; they are timeless; they do not change; they can neither be caused by something nor cause anything. Some mathematicians believe numbers to be entities of this abstract Platonic sort. And some linguists have put forward the view that sentences are such abstract objects, taking languages to be collections of sentences. Chomsky, however, has rejected this view for various reasons, two of which are particularly relevant here. First, he sees no plausibility in the idea that languages can exist as Platonic objects independent of mental states of individuals. How people would be able to acquire and use languages if they were abstract Platonic objects is not clear. Nor how languages would be able to change, which they do all the time. Second, Chonsky argues that the collections made up by sentences -.i.e., the individual languages -.- do not have clearly defined boundaries. He observes that it is unclear in the case of many semi-grammatical expressions -.- e.g., Give it me, The child seems sleeping ... whether they are inside or outside the set of sentences supposed to make up a lânguage. ${ }^{41}$

There are also non-Platonic ways of thinking of abstract objects. But it has not yet proved possible to coherently portray language as something abstract in terms of any of these. Which leaves us in a rather uncomfortable position if we find that it makes conceptually good sense to think of language as an object of knowledge, an object that has been abstracted from a mental state. An object that has been abstracted from a mental state could hardly be something mental itself. The abstractness arrived at in this way is as hard to "picture" as the nowhereness with which Tweedledee operates:

'"He [ = the King]'s dreaming now, said Tweedledee: "and what do you think he's dreaming about?"

Alice said: "Nobody can guess that."

"Why, about you!" Tweedledee exclaimed, clapping his hands triumphantly.

"And if he left off dreaming about you, where do you suppose you'd be?"

"Where I am now, of course," said Alice

"Not you!" Tweedledee retorted contemptuously. "You'd be nowhere. Why, You're only a sort of thing in his dream!"' [TLG 238]

Which isn't to say that language is made of the same stuff as entities in the dreams of people who have woken up! (What would the substance be of the language spoken by such people in their dreams? $)^{42}$ 
Suppose that Chomsky's first idea is right. Suppose, in other words, that language is something mental. What would be the nature of mental stuff? How would mental stuff differ from material stuff or, for short, matter? Recently, Chomsky has addressed these and related questions from an interesting and unusual perspective. To begin with, he denies that the mental is some 'ghost-like' substance which is distinct from matter. And he denies that the mind is distinct and separate from the body (or brain). To be able to maintain this view, he argues, one must have a definite, properly-demarcated concept of 'body' and of 'matter'. The Cartesians had such a concept. It took the form of a kind of contact mechanics that was restricted to the ways in which physical entities interact by pushing, pulling, colliding and so on. Only entities that interacted in such ways were considered to be material or 'bodily' entities.

But this concept of 'body' collapsed when the Isaac Newton (1642 - 1727) put forward his theory of physical phenomena -.- a theory justly famous in its day for the correctness of its highly precise predictions, for its conceptual coherence and for the comprehensiveness of its factual coverage. The Cartesian concept of 'body' collapsed because Newton, in order to account for phenomena as (seemingly) diverse as the tides of the sea and the motions of the planets, appealed to a principle of 'action at a distance'. Such action is caused by a force that could not exist within the limits of Cartesian mechanics, that is within what is possible in terms of the Cartesian concept of 'matter' or 'body'. And, indeed, this force was at first believed to be a 'mysterious principle' or worse, an 'occult force'. No doubt you find that belief curious. After all, even Alice, who is only a young girl, understands her plunge down the rabbit hole as an event governed by the law of gravity. But then, you see, both you and Alice benefit from a discovery made only relatively recently: that the problem lies not in the 'occultness' of the force of gravity but, instead, in the limitations of the Cartesian theory of matter or the body.

So the Cartesian theory of matter has been abandoned. Its abandonment, what is more, has a consequence which is highly important to us. Here is how this consequence is described by Chomsky:

'We no longer have a definite concept of body. Rather, the theory of body - or physics - now includes whatever concepts are necessary to account for events in the physical world: forces, massless particles, waves, strings in 10-dimensional space, or whatever. We can therefore no longer coherently ask whether some phenomenon falls outside the range of 'body'. We can only ask whether our current concepts of 'body' are adequate to account for this phenomenon;.... ${ }^{43}$ 
This means that we now have an open-ended concept of 'body' or 'matter'. And whatever scientists discover in the pursuit of normal scientific practice about the body or the mind becomes part of matter or the material world. Hence, it is not possible to take the mental to be a subsiance distinct from the material.

Language, accordingly, is something material in Chomsky's recent thinking. And, from this perspective, the language faculty is part of the body, a conclusion which may come as a surprise to the White Knight and people sharing his views on the relation between the mind and the body. As you may recall, this Knight --- the one whose mind goes on working even when he hangs head down into ditches --- believes that one talks with one's mind rather than with one's body. But if one's mind turns out to be part of one's body, ... 44

\subsection{The macroscope}

Perhaps you have been wondering all along why we have looked above at language(s) from the perspective of certain dimensions rather than others. And why, within the former dimensions, we have focused on certain properties rather than others. For instance, why haven't we considered language(s) from the perspective of diversity? From this perspective, we would find language to be manifested in a rich profusion of varieties: full individual languages, social and regional dialects, idiolects, styles, registers, sublanguages used by certain professions, recently born marginal languages such as pidgins, simplified languages of children still in the process of acquiring their mother tongue, interlanguages developed by people in the process of acquiring a second language, the language-in-attrition of people unlearning a first or second language, dying languages with a rapidly dwindling number of speakers and so on. Surely, in view of such diversity, variability might have been considered for membership of the class of salient properties of language? Or, to take another example, why haven't we looked at language(s) from the perspective of change? If we did, we would find languages to be changing all the time; so, another candidate for the status of salient property might well have been changeability. 45

To arrive at answers to questions such as these, it won"t help us to study the nature of language more closely. Rather, we have to inspect the macroscope through which we have studied language. Such inspection will reveal it to be a macroscope of a particular design: one fitted with Chomskyan lenses. Which means that we have conducted our macroscopic study of language(s) -... and of various other important architectural features of the world of language -. - within a conceptual framework compatible with Noam Chomky's thinking. And this thinking 
focuses more sharply on certain dimensions (e.g., form and structure) and certain properties (e.g., structure-dependency and long-distance dependency) than on other dimensions (e.g., diversity and change) and other properties (e.g., variability and changeability). The former dimensions and properties, Chomsky believes, are more crucial than the latter ones to our understanding of the nature of language(s).

This belief may of course be wrong. Which implies that, as we peer through our Chomskyan macroscope, we run the risk of getting an unfocused, blurred or distorted image of the nature of language(s). Risks of this kind, though, are by no means unique to Chomskayn linguistics. We run such risks whenever and where-ever we study objects that we cannot inspect directly by using our senses only. Language and languages are just such objects: they cannot be studied without the aid of finely ground conceptual lenses. And it is simply impossible to grind conceptual lenses in a way that will guarantee their users some distortion-free, 'completely neutral', image of the objects under investigation.

For inspecting language(s), Chomskyan macroscopes --- and microscopes as well --- are among the best that one could use at present. As has been noted by John Lyons, a linguist respected for his balanced judgement:

'... the influence of Chomsky's thought continues to be dominant in any branch of linguistics that aspires to theoretical status. ${ }^{46}$

And:

'... his [i.e., Chomsky's] work has inspired, and continues to inspire an immense amount of research and discussion in any and every discipline that bears at all on the nature of language and mind. ${ }^{47}$

These comments of Lyons's lead us right on to the link between Noam Chomsky and Lewis Carroll: considered from the viewpoint of creativity, they are 'two of a kind". When it comes to designing dreanworlds, Lewis Carroll is in a class of his own. Which is just what Noam Chomsky turns out to be when it comes to designing conceptual lenses for the study of language(s). 


\section{Notes to Chapter 4}

1 In note 5 appended to the text, readers are told that "Mock turtle soup is an imitation of green turtle soup, usually made from veal. This explains why Tenniel [the original illustrator of the Alice stories] drew his Mock Turtle with the head, hind, hoofs and tail of a calf." $[A I W 124]$

2 See par. 3.1.1.1 above.

3 The phonological structure of the third box corresponds to what is indicated as the 'phonetic plan' in Figure 1 in par. 3.1.1.1 above.

$4 \quad$ See par. 3.1.1.2 above.

5 This also applies to written and signed language, two secondary means of behaving linguistically. For some discussion of the relation between speaking and writing, see par. 2.3.2 above. And for some observations on the relation(s) between spoken utterances, written utterances and signed utterances, see par. 1.1.1.

For a recent functional characterization of language as a means of conversion, translation or mapping, see in particular Jackendoff 1994:39-43. As noted by Chomsky (1994c:49), this kind of functional characterization of language is anticipated in the traditional conception of a language as 'a way to speak and understand'. Some linguists have tried to capture the nature of language by portraying it metaphorically as a (conversion) 'code'. For instances of this portrayal, see, for example, Lyons 1981:1724, Jackendoff 1990:737 and, more recently, Pinker 1994:87ff.

7 For the former characterizations by Chomsky, see Chomsky 1988b:5, 1994c:49. For the Humboldtian roots of these characterizations, see Chomsky 1988b:4. For further discussion of the generative nature of language, see also Bloom 1994, Corballis 1994. In par. 4.2 .5 below we will return to the idea of the infinity of language.

8 For some of the reasons for introducing two levels of syntactic structure, see par. 4.3.4 below. Chomskyan linguists have argued that, in order for linguistic theories to achieve explanatory adequacy, the informal power or richness has to be restricted. On the specifics of this view, see Chomsky 1986:51, 52-53, 1994a:1-4, Botha 1989:169-170.

9 For some discussion of the productivity of language, see Lyons 1981a:22-23, 230-231. The conception of productivity expounded by Lyons is narrower than the one that we have considered above. On the use of the notion of 'effability' in this context, see, for example, Katz 1981:225-226, Akmajian et al. 1990:7.

10 For a discussion of the arbitrary nature of the relation between the form and meaning of words, see Saussure 1983:67-69, Lyons 1977:70-71, 101-105, 1981a:19-20. Saussure took a linguistic sign to be a unit with two 'opposite sides' --- a signifying side or sound image and a signified side or concept--- linked by a relation of arbitrariness. For the 
distinction between symbols and icons, see Peirce 1933, Part II:249, Lyons 1977:99. 105. Denoting a particular kind of relation between the forms and the meanings of words, the term arbitrariness is used in a narrow sense. As noted by Lyons (1977:7071 ), the term is used in a wider sense as well to 'describe any feature of [language] that cannot be said to derive from the properties of the channel along which language is normally transmitted, from the physiological and psychological mechanisms employed in the production or reception of language or from the functions language is called upon to perform'.

11 For some discussion of the 'advantages' and 'disadvantages' of 'the principle of the arbitrariness of the linguistic sign', see, for example, Traugott and Pratt 1980:4-5, Lyons 1981a:19-20, Pinker 1994:83-84, Pinker and Bloom 1990:718.

12 Rules $1-3$ were introduced in paras. $3.2 .2 .1,3.4$ and 3.3 .1 respectively.

13 For the linguistic universals $4-6$, see paras. $3.3 .1,3.3 .3$ and 3.3 .4 respectively.

14 For this point, see par. 3.2.1.3.

15 For the principles-and-parameters conception of what language is, see, for example, Chomsky 1981a, 1986:46, 150-151, 243, 1992:5-6, Botha 1989:88-90. The illustration given above of the nature of principles and parameters is based on Pinker 1994:106112. More recently, Chomsky (1994c:51, 1992, 1994a) has argued that even such principles may themselves be epiphenomena. The gist of Chomsky's argument is that the consequences of these principles can be reduced to what he (1994c:51) calls "more general and abstract properties of the computational system, properties that have a kind of "least effort" flavor'. These properties characterize what Chomsky (1992:2, 1994b:388) also refers to as 'principles of economy' or 'economy conditions'. The reduction of the kind of principles provided for in the principles-and-parameters conception of language to the latter, deeper, principles of economy forms a core component of the 'minimalist program' for linguistic theory which is outlined in, for example, Chomsky 1992, 1994a. Marantz 1994 offers 'A Reader's Guide to "The Minimalist Program for Linguistic Theory"' (i.e., to Chomsky 1992).

16 The outline given above of the distinction between discrete combinatorial systems and blending systems is based on Pinker's (1994:84-85) lucid account. Pinker (1994:85) offers one further example of a discrete combinatorial system: 'the genetic code in DNA, where four kinds of nucleotides are combined into sixty-four kinds of codons, and the codons can be strung into an unlimited number of different genes'. And he (1994:85) cites 'geology, paint mixing, cooking, sound, light and weather' as other examples of blending systems (which predominate among the complicated systems in the world). For further discussion of discreteness as a property of (some of the) units used by (human) language, see, for example, Martinet 1964:31-33, Lyons 1977:78-79, 
1981a:21-22. On how animal communication systems compare with (human) language in regard 10 discreteness, see, for example, Hockelt 1960, Chomsky 1966:77-78, McNeill 1970:chapter 4. McNeill uses the expression 'combining system' to denote (human) language as a discrete combinatorial system; he uses the expression 'graded systen' to denote non-discrete animal communication systems. For a useful survey both of work on fundamental properties of various animal communication systems and of various camparisons of animal communication systems with (human) language, see Akmajian et al. 1979:chapters 2-5.

17 For some discussion of duality as a basic property of language and of the way in which duality interacts with such other properties as discreteness and arbitrariness see, for example, Martinet 1964:22-24, Lyons 1977:71-76, 1981a:20-21, Pinker 1994:162-163.

18 For further discussion of how recursiveness has, over the years, been seen and accounted for in generative grammar, see Chornsky 1957:23-24, 1965:37, Bach 1974:194-196, Culicover 1976:27, 178-183, Jackendoff 1994:74-75.

19 For the characterization of a language as an infinite set of sentences, see Chomsky 1957:13. The status of this characterization in Chomsky's evolving thinking about language is considered in, amongst others, Steinberg 1975:220-221, Botha 1989:72-73.

20 For Chomsky's views on how (human) language differs in regard to discrete infinity from animal communication systems, see Chomsky 1980a:38-39, 1987a:16-17, 1987b:7, 1987c:13. As far as Chomsky (1987a:16-17) knows, there is only one other 'behavioral phenomenon" that shares properties of discrete infinity exhibited by language and that involves similar principles of digital computation: the human number faculty. In his (1980a:38) view, the very essence of the number system is the concept of adding one, indefinitely. Chomsky (1987a:16-17) also considers another finding quite surprising: the finding that the language faculty, as a part of the mind, is in crucial respects a system of digital computation of a highly restricted character.

21 The following illustration of the structure-dependent nature of grammatical rules is based on Chomsky's lucid (1988a:41-46) account of the principle of structuredependency with reference to the rule for forming yes/no questions in Spanish. For reference to other discussions of this principle, see also note 48 to chapter 3 above. Within the framework of Chomsky's principles-and-parameters conception of language or that of his more recent 'miminalist program', structure-dependency would be a reflection of a property or cluster of properties of the deeper --- and therefore nonepiphenomenal -.- entities from which grammatical rules can be derived.

22 Within the framework of Chomsky's principles-and-parameters conception of language or that of his more recent 'minimalist program', structure dependency would reflect a 
property or a cluster of properties of the deeper (i.e., non-epiphenomenal) entities from which grammatical rules such as the yes/no question rule can be derived.

23 For useful introductory discussions of the nature of phrase structure, see, for example, Pinker 1994:97ff., Jackendoff 1994:70ff. Pinker offers a clear account of the reasons for assuming that 'sentences are trees', as he puts it. For a more detailed introduction to the properties of phrase structure, see, for example, Van Riemsdijk and Williams 1986: chapter 3, Haegeman 1991 :chaper 2.

24 For these remarks, see Pinker 1994:99-100.

25 For fuller discussions of structural discontinuity as a basic property of sentences, see, for example, Akmajian et al. 1990:157-162, Chomsky 1994b:389, Pinker 1994:89ff. How the interpretation of echo questions helps linguists to understand that of $w / 2$ questions is lucidly explained in Jackendoff 1994:76. As Jackendoff (1994:77) shows, 'quizz-show' questions --- such as 'Mr. Van Doren, for $\$ 64,000$ : on the morning of July 4, 1776, General Washington ate what for brakfast?' -.- are similarly helpful to linguists for coming to grips with the way in which wh-questions are understood.

27 For a recent (re)statement of this view, see Chomsky 1994b:389.

28 The wh-questions $37 \mathrm{a}-\mathrm{f}$ correspond to the declarative sentences $\mathrm{i}$-vi respectively. In the questions, $t$ marks the position in which the italicized phrases occur in these declarative sentences.

(i) The Knight believed that the King thought that the Hatter told the March Hare that the Queen would order the Executioner to behead the cook on the croquetground.

(ii) The Executioner wore a top hat and a bow tie for carrying out his duties.

(iii) The croquet game was played on the day that the White Queen fired the intellectual Executioner.

(iv) For the Executioner to get a pay rise is easy.

(v) The Queen hired a new Executioner who uses a hi-tec axe.

(vi) Alice wondered who would get the job of depury Executioner.

29 For a non-technical, introductory, account of the nature of long-distance dependencies, the various kinds of sentences (not wh-questions alone) that incorporate them and the source of the constraints on such dependencies, see Jackendoff 1994:75-80. For a fuller account of the various constraints on such dependencies see, for example, Van Riemsdijk and Williams 1986:chapters 2 and 5 and also the literature cited there. For a more recent, fairly technical account of these constraints, see Haegeman 1991:364-373. On the 'super-rules' or universal constraints which rule out the wh-questions $37 \mathrm{~b}$-f, see Van Riemsdijk and Williams 1986:20-23. 
30 See Chomsky 1994b:389 for the essence of the proposal that the relation of a moved phrase to the position of its interpretation is that of a transformation.

31 For a first introductory account of the distinction between deep structure and surface structure and of the nature of syntactic transformations, see Akmajian et al. 1990:162165, Jackendoff 1994:75-77, and Pinker 1994:120-124. For a more detailed introductory account of the nature and function of syntactic transformations see Haegeman 1991:271-282. For Chomsky's most recent 'minimalist' view of the status of the distinction between deep and surface structure, see Chomsky 1992, Marantz 1994.

32 For the view that traces are unpronounced pronouns, see Jackendoff 1994:77. On the idea that traces serve as 'reminders' of the role that a moved phrase is playing, see Pinker 1994:122.

33 For this argument see Chomsky 1992:27ff. What is at stake is the existence of 'Dstructure' and 'S-structure', which are highly 'technical' versions of the original constructs 'deep' and 'surface structure', respectively. On the relevant controversy between followers and opponents of Chomsky, see, for example, Newmeyer 980: shapter 5 .

34 See Abler (1989) for the view that hierarchicality characterizes, in addition to human language, several other 'naturally-occurring systems', including 'chemical interaction' and 'biological inheritance'. For an introductory discussion of the way in which words are structured phonologically, see pinker 1994:173-175. For a more technical account, see Carr 1993:chapter 9 . The phonological structures of the words in a sentence form but one aspect of the phonological structure that the sentence has as a whole. For an account of some of the other aspects, see Clark and Yallop 1990:chapter 10, Goldsmith 1990, Carr 1993, Pinker 1994: chapter 6, Kenstowicz 1994.

35 For the Korean example, see Jackendoff 1994:76. For an attempt to provide some kind of motivation for the direction of wh-movement, see Haiman 1985:238-239.

36 The general idea that grammatical form is independent of meaning, function or use has been defended by Noam Chomsky in the form of his thesis of the autonomy of formal grammar. For some of the versions of this thesis, see Chomsky 1975. For a discussion of (problems with) various views holding that grammatical form is not autonomous in Chonsky's sense, see Newmeyer 1983:chapter 4. For some discussion of the ways in which various parts of language are "tailored to mapping a characteristic kind of semantic or pragmatic function onto a characteristic kind of symbol sequence', see Pinker and Bloom 1990:713-714.

37 For a general characterization of iconicity, see Lyons 1977:102-105. For some discussion of reduplication and repetition, see, for example, Persson 1974, Moravscik 1978. and Botha 1988. (The Tzeltal, Mandarin and Thai reduplications are from 
Moravscik 1978.) For some discussion both of the various kinds of iconicity found in natural language and of what are claimed to be functionally motivated aspects of linguistic form, see, for example, Haiman 1985, 1994, Haiman (ed.) 1985.

38 See Chonsky 1994c:51-52 for the above views on the usability of language. For a discussion of the problems which the interpretation of sentences $43 \mathrm{a}-\mathrm{d}$ posed for Alice, see Holmes 1971:164-165.

39 For an account of Chomksy's thinking on the substance (or what he calls 'nature') of language, see Botha 1992:chapter 3. On various reactions to Chomsky's ideas and on his appraisal of these reactions, see Botha 1992: chapter 3.

40 For the ideas of Chomsky's considered above, see Chomsky 1986:22-26, 1987a:17, 1988a:36, 1988b:21 and Botha 1992:90-93.

41 For the view that languages are abstract Platonic entities, see Katz 1981, Katz and Postal 1991, Botha 1992:149-168. For problems with this view, see Chomsky 1986:1927, Botha 1992:168-182.

42 For a non-Platonic position on which languages are abstract objects, see Popper 1977:38-49, Carr 1990:37ff., Botha 1992:183-198. Various linguists and philosophers have proposed that languages are neither material nor mental nor abstract objects but, instead, are 'social' objects. For a survey and an appraisal of these proposals, see Botha 1992: chapter 5 .

43 See Chomsky 1987a:5.

44 For Chomsky's recent views on the relation between the mind (the mental) and the body (the material), see Chomsky 1987a:1-6, 1989:5, Salkie 1990:80, Botha 1992:94. 97, 143-144. Views essentially similar to Chomsky's have been put forward by Fodor. For some discussion of these views of Fodor's, see Rey 1991:xii.

45 In Chomsky's (1992:4-5) view, the range of permissible variation among languages is restricted. He assumes, in the context of his 'minimalist program', that variation must be determined by what is 'visible' to the child acquiring language, that is, by what is known as the 'primary linguistic data'. And given this assumption, he does not consider it surprising that a degree of variation is found in the 'phonetic form component' and the lexicon. For a completely different kind of perspective on linguistic diversity, a Whorfian one, see Mühlhäusler 1993.

46 See Lyons 1991:206.

47 See Lyons 1991:209. 


\section{Bibliography}

Abler, W.L. 1989. On the particulate principle of self-diversifying systems. Journal of Social and Biological Structures 12:1-13.

Akmajian, A., Demers, R.A., Farmer, A.K., Harnish, R.M. 1990. Linguistics. An Introduction to Language and Communication. Third Edition. Cambridge, Mass.: MIT Press.

Akmajian, A., Demers, R.A., Harnish, R.M. 1979. Linguistics: An Introduction to Language and Communicarion. First Edition. Cambridge, Mass.: MIT Press.

Asher, R.E. (ed.) 1994. The Encyclopedia of Language and Linguistics. Oxford: Pergamon Press.

Bach, E. 1974. Syntactic Theory. New York: Holt, Rinehart and Winston, Inc.

Bloom, P. 1994. Generativity within language and other cognitive domains. Cognition 51:177. 189.

Botha, R.P. 1988. Form and Meaning in Word Formation. A Study of Afrikaans Reduplication. Cambridge, etc.: Cambridge University Press.

Botha, R.P. 1989. Challenging Chomsky. The Generative Garden Game. Oxford: Basil Blackwell.

Botha, R.P. 1992. Nventieth Century Conceptions of Language. Mastering the Metaphysics Market. Oxford: Basil Blackwell.

Carr, P. 1990. Linguistic Realities. An Autonomist Metatheory for the Generative Enterprise. Cambridge Studies in Linguistics 53. Cambridge: Cambridge University Press.

Carr, P. 1993. Phonology. London: Macmillan.

Chomsky, N. 1957. Syntactic Structures (= Jamua Linguarum IV). The Hague: Mouton.

Chomsky, N. 1965. Aspects of The Theory of Syntax. Cambridge, Mass.: MIT Press.

Chomsky, N: 1966. Cartesian Linguistics. New York: Harper and Row.

Chomsky, N. 1975. Reflections on Language. New York: Pantheon Books.

Chomsky, N. 1980a. Rules and Representations. New York: Columbia University Press.

Chomsky, N. 1981a. Principles and parameters in syntactic theory. In Hornstein and Lightfoot (eds.) 1981:32-75.

Chomsky, N. 1986. Knowledge of Language: Its Nature, Origin and Use. New York: Praeger. Chomsky, N. 1987a. Language in a Psychological Setring. (Sophia Linguistica 22). Tokyo: The Graduate School of Languages and Linguistics.

Chomsky, N. 1987b. Generative Grammar. Its Basis, Development and Prospects. S.E.L.L, (Special Issue of Bulletin of English Department). Japan: Kyoto University.

Chomsky, N. 1987c. Language and problems of knowledge. Revised version of paper delivered at a conference in Madrid, 28 April 1986. 
Chomsky, N. 1988a. Language and Problems of Knowledge. Cambridge, Mass.: MIT Press.

Chomsky, N. 1988b. A personal view. Paper presented at conference Linguistics and Adjacent Fields: The State of the Art, Israel, April 1988. Published in Kasher (ed.) 1991:3-25.

Chomsky, N. 1989. Mental constructions and social reality. Paper delivered at conference on Knowledge and Language held in Groninger, May 1989.

Chomsky. N. 1992. A Minimalist Program for Linguistic Theory. (= MIT Occasional Papers in Linguistics 1). Cambridge, MA: MT. (Also published in Hale and Keyser (eds.) 1993:1-52.)

Chomsky, N. 1994a. Bare Phrase Structure. (= M/T Occasional Papers in Linguistics 5). Cambridge, MA.: MTT.

Chomsky, N. 1994b. Notes on linguistics and politics. Interview with Günther Grewendorf. Linguistische Beriche 153:386-395.

Chomsky, N. 1994c. Language and Thought. Wakefield, R.1. and London: Moyer Bell.

Clark, J. and Yallop, C. 1990. An Introduction to Phonetics and Phonology. Oxford: Basil Blackwell.

Corballis, M.C. 1994. The generation of generativity: a response to Bloom. Cognition 51:191198.

Culicover, P.W. 1976. Syntax. New York: Academic Press.

Goldsmith, J. 1990. Autosegmental and Metrical Phonology. Oxford: Basil Blackwell.

Greenberg, J.H. (ed.) 1978. Universais of Human Language. Volume 3. Stanford: Stanford University Press.

Haegeman, L. 1991. Introduction to Government and Binding Theory. Oxford: Basil Blackwell.

Haiman, J. (ed.) 1985. Iconicity in Synax. Amsterdam: John Benjamins.

Haiman, J. 1985. Naural Syntax. Cambridge: Cambridge University Press.

Haiman, J. 1994. Iconicity. In Asher (ed.) 1994, Vol. 3:1629-1633.

Hale, K. and Keyser, S.J. 1993. The View from Building 20. Cambridge: MIT Press.

Hockett, C.F. 1960. The origin of speech. Scienific American 203:88-111.

Holmes, R.W. 1971. The philosopher's Alice in Wonderland. In Phillips (ed.) 1971:199-207.

Hornstein, N. and Lightfoot, D. (eds.) 1981. Explanation in Linguistics. The Logical Problem of Langurge Acquisition. London and New York: Longman.

Jackendoff, R. 1990. What would a theory of language evolution have to look like? Behavioral and Brain Sciences 13:737-738.

Jackendoff, R. 1994. Patterns in the Mind. Language and Human Nature. New York: Basic Books.

Kasher, A. (ed.) 1991. The Chomskyon Turn. Oxford: Basil Blackwell.

Katz, J.J. 1981. Language and Other Abstract Objects. Oxford: Basil Blackwell. 
Katz, J.J. and Postal, P.M. 1991. Realism vs. conceptualism in linguistics. Linguistics and Philosophy 14:515-554.

Kenstowicz, M. 1994. Phonology in Generative Grammar. Oxford: Basil Blackwell.

Loewer, B. and Rey, G. (eds.) 1991. Meaning in Mind. Fodor and his Critics. Oxford: Basil Blackwell.

Lyons, J. 1977. Semanics. Vols. 1 and 2. Cambridge, etc.: Cambridge University Press.

Lyons, J. 1981a. Language and Linguistics. An Introduction. Cambridge, etc.: Cambridge University Press.

Lyons, J. 1991. Chomsky. Third Edition. London: Fontana.

Marantz, A. 1994. A reader's guide to 'The Minimalist Program for Linguistic Theory'. Unpublished Paper. MIT.

Martinet, A. 1964. Elements of General Linguistics. Translated by Elisabeth Palmer. London: Faber and Faber.

McNeill, D. 1970. The Acquisition of Language. New York: Harper and Row.

Moravscik, E.A. 1978. Reduplicative constructions. In Greenberg (ed.) 1978:297-334.

Münlhäusler, P. 1993. What is the use of language diversity? Inaugural Lecture, University of Adelaide.

Newmeyer, F.J. 1980. Linguistic Theory in America. The First Quarter-Century of Transfomarional Generative Grammar. New York: Academic Press.

Newmeyer, F.J. 1983. Grammatical Theory. Its Limits and Its Possibilities. Chicago and London: University of Chicago Press.

Newmeyer, F.J. 1991. Functional explanation in linguistics and the origins of language. Language and Communication 11:3-28.

Peirce, C.S. 1933. Collected Papers of Charles Sanders Peirce. Parts I-VIII. Edited by C. Hartshorne and P. Weiss. Cambridge, Mass.: The Belnap Press of Harvard University Press.

Persson, G. 1974. Repetition in English. Part 1: Sequential Repetition. (Acta Universitatis Upsaliensis: Sudia Anglisica Upsaliensia 21). Uppsala.

Phillips, R. (ed.) 1971. Aspects of Alice. Penguin Books.

Pinker, S. 1994. The Language Instincr. How the Mind Creares Language. New York: William Morrow and Company.

Pinker, S. and Bloom, P. 1990. Natural language and natural selection. Behavioral and Brain Sciences 13:707-784.

Popper, K.R. 1977. Part I of The Self and Its Brain by K.R. Popper and J.C. Eccles. Berlin: Springer-Verlag.

Popper, K.R. and Eccles, J.C. 1977. The Self and its Brain. An Argument for Interactionism. Berlin: Springer-Verlag. 
Rey, G. 1991. Introduction to Loewer and Rey (eds.) 1991:xi-xxxvii.

Salkie, R. 1990. Chomsky Update. Linguistics and Politics. London: Unwin Hyman.

Saussure, F.de. 1983. Course in General Linguistics. Translated and annotated by Roy Harris. London: Duckworth

Steinberg, D.D. 1975. Chomsky: from formalism to mentalism and psychological invalidity. Glossa 9:218-252.

Traugott, E.C. and Pratt, M.L. 1980. Linguistics for Students of Literature. New York, etc.: Harcourt, Brace, Jovanovich, Inc.

Van Riemsdijk, H. and Williams, E. 1986. Introduction to the Theory of Grammar. Cambridge, Mass.: MIT Press. 
CONTENTS OF PREVIOUS ISSUES OF SPIL PLUS

SPIL PLUS 1 (1980)

Jeanne Maartens

Nuwe ontwikkelings binne Chomsky se teorie van kerngrammatika

SPIL PLUS 2 (1980)

Alta Oosthuizen

Leksikale basiskategorieë. Probleme vir die "working grammarian"

SPIL PLUS 3 (1980)

Jeanne Máartens

Afrikaanse Sintaksis: 'n evaluering

SPIL PLUS 4 (1981)

Walter Winckler

Aspekte van die taksonomiese taalkunde

SPIL PLUS 5 (1981)

FONOLOGIE, SEMANTIEK, TAALPOLITIEK: DRIE BESPREKINGS

R.P. Botha

Oor vrye kritiese meningswisseling en die skete van peripatete

J. Roux

Praktiese fonetiek vir taalsrudente ..... : 'n Evaluering

C. le Roux en M. Sinclair

'n Kritiese beskouing van Inleiding tot die Semantiek

R.H. Pheiffer

Bedenkinge oor die politieke kader van Thiste in eie taal

SPIL PLUS 6 (1982)

REPLIEK EN KRITIEK

J.C. Steyn

Bedenklike Bedenkinge: Pheiffer se Taalpolitiek

D.P. Wissing

Fonetiek vir Eerstejaars: 'n kort waardering

SPIL PLUS 7 (1982)

\section{CHOMSKY IN DIE JARE TAGTIG}

R.P. Botha

'n Roete deur die wêreld van Chomsky

W.K. Winckler

Rules and Representations: Lees maar ... Daar staan wel wat daar staan 


\section{SPIL PLUS 8 (1983)}

TAALWETENSKAP EN DIE STUDIE VAN LITERATUUR

Rudolf P. Botha

Wat kan Taalwetenskap die student van literatuur bied?

Arnold Blumer

Basiskonsepte vir die doseer van taal en literatuur in die konteks

van 'n vreende kultuur

Wilhelm Liebenberg

Die rol van die Taalwetenskap in die ontwikkeling van die

Literatuurwetenskap

Henning Snyman

Implikasie as taalverskynsel

Johan C. Thom en Pieter G.R. de Villiers

Die relevansie van ' $n$ linguistiese benadering tot die analise van

klassieke tekste

\section{SPIL PLUS 9 (1984)}

Hester Waher

Chomsky se teorie van 'government-binding'

SPIL PLUS 10 (1985)

\section{AFDELING !}

ALGEMENE PERSPEKTIEWE OP DIE NORMERING VAN TAALGEBRUIK

D.D. Joubert

'n Sosiologiese konsepsie van norme

J.C. Steyn

Algemene aspekte van taalnormering

V.N. Webb

$70-108$

Taalnorme en Afrikaans. 'n Geval van twyfel en vertwyfeling?

W.K. Winckler

Oor die taalwetenskaplike gronde van taalgebruiksnorme:

"important" of "importantly"?

R.P. Botha en M. Sinclair

Die negende gebod in taalgebruik.

\section{AFDELING II}

PERSPEKTIEWE OP DIE PRAKTYK VAN DIE NORMERING VAN AFRIKAANS

E. Raidt

Historiese perspektief op die normering van Afrikaans

L.C. Eksteen

Die rol van die Akademie in die standaardisering van die Afrikaanse spelling

D.C. Hauptfleisch

Taalnormering en woordeboeke: 'n Praktykgerigte perspektief 
T.J.R. Botha

Normering in die Afrikananse Radio- en Televisiediens

J. Picard

Die normering van Afrikaanse vakterminologie

Die taalpraktisyn as kruispunt

D.W. le Roux

Die Staatstaaldiens: Funksies en invloed ten opsigte van die normering van taalgebruik

G. Kroes

Die doeltreffendheid van die Afrikaanse Woordelys en Spelreëls as handleiding en naslaanbron by die onderrig van Afrikaans op tersière vlak

J.P. Botha

Die normering van Afrikaanse taalgebruik soos beoefen in die skool en die universiteit

J.M. Marais

Taainormering in die skool: 'n onderwyser se perspektief

J. Esterhuyse

Die dominasie van die Afrikaner-lewensbeskouing binne die

Arrikaanse spraakgemeenskap, soos gemanifesteer in taalhandboeke vir hoërskole

L.R. Heiberg

Taaldokters

A. Gardiner

Die Afrikaanse taaldokter en die Hippokratiese eed: implikasies

vir die taalgebruiker

H. Snyman

Norme by literêre taalgebruik

Die normering van Afrikaanse Bybeltaal

AFDELING III

PERSPEKTIEWE OP DIE NORMERING VAN ANDER TALE

E. Loubser

Normering op die Nederlandse taalgebied

$489-496$

E. Ridge

Norms in British and South African English

S. Skorge

Norme en normkritiek ten opsigte van die Duitse taal:

'n kort oorsig

P. Brink

Taalnormering in Frankryk 
J.M. Lenake \& C.F. Swanepoel

Historiese aspekte van normering in Suid-Sotho

Taalgebruiksnormering in die Suid-Afrikaanse Bantoetale

SPIL PLUS 11 (1987)

Rudolf P. Botha

The generative garden game: challenging Chomsky at conceptual combat

SPIL PLUS 12 (1989)

Jan B. Bedaux

The portraits of Simon van der Stel, first governor of the Cape

SPIL PLUS 13 (1989)

C. Ie Roux

On the interface of morphology and syntax

SPIL PLUS 14 (1989)

Rudolf P. Botha

The Metaphysics Market. 1 Merchandizing language as matter

\section{SPIL PLUS 15 (1989)}

Rudolf P. Botha

The Metaphysics Market. 2 Billing language as behavioural

SPII, PLUS 16 (1991)

Hester Waher

Oor grense, kettings, en lisensies. 'n Sleutel tot Chomsky se teorie van grammatika

SPIL PLUS 17 (1991)

Rudolf P. Botha

The Metaphysics Market. 3 Selling language as soul

\section{SPIL PLUS 18}

M. Sinclair and W.K. Winckler

Relevance Theory. Explaining verbal communication

SPIL PLUS 19 (1991)

Rudolf P. Botha

The Metaphysics Market. 4 Pushing language as Platonic (not to mention Popperian)

SPIL PLUS 20 (1991)

Rudolf P. Botha

The Metaphysics Market. 5 Stocking language as something social 
SPIL, PLUS 21 (1992)

TAALWETENSKAP VIR DIE TAALPROFESSIES 1: DEEL A LINGUISTICS FOR THE LANGUAGE PROFESSIONS 1: PART A

R.P. Botha

Charting the anatomy of linguistic reality

Johann L. van der Walt

Linguistics and second language teaching: An assessment

Gary P. Barkhuizen

What we want from linguistics: A plea from high school

English teachers

Elizabeth de Kadt

Contrastive analysis, pragmatics and language teachers?

Why language teachers need linguistics

Elaine Ridge

Communicative language teaching: Time for review?

M.S. Odendaal

Peter Southey

Fossilization in English second language medium

$140 \cdot 158$

H.W. Broekman

Circular interaction between linguistic departments and language : departments

Marianna Visser

$159-185$

Theoretical syntax in second language acquisition research and in second language classroom research

M. Viljoen

186-2i7

Wat is dit wat ons met behulp van 'n taal toets evalueer?

Norah Haussmann

What exactly are we testing when we claim to be testing mother-

tongue communicative competence?

J. de Vynck

Taalgebruik en taalbeheersing: twee Franse modelle

I. Keith Chick

A role for linguistics in addressing contextual issues relevant to second language teaching

Christine Anthonissen

The relevance of speech act theory for research on the acquisition of pragmatic competence by second language learners

Cecile le Roux

The problem of ethnocentric bias in speech act studies: Implications for language teaching 
Kay Mc Cormick

Sociolinguistics and first language teaching

Jeanne Maartens

The disadvantaged non-mother-tongue speaker as university student

of Afrikaans: Possible solutions to the language lecturer's dilemma

Rosemary Granger

$360-374$

The problem of non-standard utterances used by speakers of English as a second language at tertiary level

Margaret Inglis

The interrelationship of proficiency in a second language and understanding of scientific concepts

Ninon Roets

Insette uit die toegepaste linguistiek vir "n kursus vir akademiese doeleindes

E. Hilton Hubbard

Linguistics as a subversive activity: Exploding myths and

misconceptions in the language classroom

H. Menkveld

Die problematiek rondom die onderrig van Afrikaans (TI)

Hildegard van $\mathrm{Zweel}$

Factors influencing the transition from orality to literacy

Myrtle Hooper

The rhetorics of audience consciousness: A dialogic approach to reading Donne in Zululand

Lydia McDermott

Literary analysis and exposition: The second language reader-writer

\section{SPIL PLUS 22 (1992)}

TAALWETENSKAP VIR DIE TAALPROFESSIES 1: DEEL B

LINGUISTICS FOR THE LANGUAGE PROFESSIONS I: PART B

LITERêRE KRITIEK EN ANALISE / LITERARY CRITICISM AND ANALYSIS

Henning H.I. Snyman

Paradigma en parodie

Linguistiese ondersoek en gediganalise: noodwendige verstrengeling of marginale oorvleueling?

J.T. von Gruenewaldt

The relevance of linguistic theories in the analysis of literary texts

\section{VERTALING EN TEKSWETENSKAP / TRANSLATION AND TEXT LINGUISTICS}

Melinda Sinclair

The effects of context on utterance interpretation: Some questions and some answers 
Ferdinand Deist

Bible translation and relevance theory

The theologian's search for "Meaning": Restraint or liberation of

the creative spirit?

C. van Schalkwyk

Vertaling - 'n diskursiewe doenigheid

G. Kroes

$134-156$

Die inhoud en plek van norme in die vertaalpraktyk, vertaalkunde, vertaalkritiek en die vertaalwetenskap

J. du T. Mclachian

Terug na Trap der Jeugd: 'n praktykbeskouing van die resultaat van taalopleiding

Anna-Marie Beukes

$175-191$

Die vertaalberoep en taalbeplanning

Walter K. Winckler

Missing Matthew's meaning. Or: Towards a nodding acquaintance

with 'Textual Meaning' (and, maybe, with 'Context' too)

Judith A. Campuell

$225-238$

Semantic representation and the translation of poetry

$239-259$

M.E. Nelson

Perspektiewe uit die tekswetenskap op die vertaling van eiename in "n kinderboek

Alet Kruger

Die beredeneerde betoog in die afstandonderrig van vertalers

\section{LEKSIKOGRAFIE / LEXICOGRAPHY}

Piet Swanepoel

273-294

Leksikografie en linguistiek

F.J. Lombard

Leksikograàf, woordeboekgebruiker en taalwetenskaplike:

'n kongruente of inkongruente driehoek?

John R. Taylor

How many meanings does a word have?

$348: 357$

A.E. van Niekerk

Betekenis en gebruik in 'n omvattende woordeboek

$358-370$

Maria Smit

Translating culture-bound words: A problem in bilingual lexicography

Ernst F. Kotzé

Die probleem van grammatikale ekwivalensie by ' $n$ vertalende aanleerderswoordeboek 
Klaus Menck

Die woordeboek as hulpmiddel - en nie as struikelblok - in vreemdetralonderrig

\section{SPRAAKTERAPIE / SPEECH THERAPY}

E. Alant

Die tersaaklikheid van taalwetenskap vir spraakheelkunde

Jenny Pahl

Speech-language therapy with Zulu clients: Implications for linguistics

INLIGTINGKUNDE / INFORMATION SCIENCE

L.G. de Stadler and M.W. Coetzer

A morphological parser for Afrikaans

\section{TAALBEPLANNING / LANGUAGE PLANNING}

C.S. Johl

Die relevansie van linguistiek en literatuurwetenskap in ${ }^{2} \mathrm{n}$ post-apartheidgemeenskap

David Brown

Sociolinguistic practice and political change: Critical appraisal of the language atlas of South Africa

Walter McKay

Marginal limitations: Report from a vanishing empire

V. Prabhakaran

The political situation as a factor in shift and maintenance of the

Telugu language in South Africa

SPIL PLUS 23 (1994)

Paul T. Roberge

The formation of Afrikaans

\section{SPIL PLUS 24 (1994)}

Rudolf P. Botha

The World of Language: 1 Its crust

\section{SPIL PLUS 25 (1994)}

Rudolf P. Botha

The World of Language: 2 Its behavioural belt

\section{SPIL PLUS 26 (1994)}

TAALWETENSKAP VIR DIE TAALPROFESSIES 2

LINGUISTICS FOR THE LANGUAGE PROFESSIONS 2

TAALTEORIE: IMPLIKASIES / LINGUISTIC THEORY: IMPLICATIONS

Roy Dace

Omissibility and learnability. Can UG really provide insights for SLA? 
Cecile le Roux

Modular minds and input in second language acquisition

H.J. Lubbe

Parameterverstelling en tweedetalverwerwing

TAALTEORIE: TOEPASSINGS / LINGUISTIC THEORY: APPLICATIONS

Yvonne Barnard

A language plan for primary school teacher education

Heila Jordaan

Language intervention to facilitate the acquisition of a second language by pre-school children

Philip Lewis

The acquisition of clicks by non-mother-tongue speakers

C. van der Walt

The acquisition of transactional competence in writing: a case study

TAALVERSKEIDENHEID: MANIFESTASIES EN IMPLIKASIES /

LINGUISTIC DIVERSITY: ITS MANIFESTATIONS AND IMPLICATIONS

Elizabeth Mathakga Botha

$143-153$

Manifestation of language varieties in the classroom in the PWV

Kate McCallum

The practical implications for writers, publishers, and policy-makers

of the various policy options on the medium of instruction in future

South African schools

R. Mesthrie

Standardisation and variation in South African English

Abner Nyamende

Regional variation in Xhosa

\section{STILISTIEK / LINGUISTIC STYLISTICS}

E. Hitton Hubbard

A functional-syntactic perspective on gender stereotyping in popular fiction

J.T. von Gruenewaldt

A stylistic approach to the teaching of poctry with specific reference to Sepamla's poem The Blues is You in Me

\section{KRITIESE TAALWETENSKAP / CRITICAL LINGUISTICS}

Christine Anthonissen

Distinguisling between critical linguistics and critical language

awareness: implications for first language teaching in secondary schools

R.P. Botha

Teaching language with the aid of Rottweilers, sharks and dinosaurs

Jenny Clarence

"Tensed" and "bumpered" in a university context: the case for the integration of critical linguistics into language programmes 
Jeanne Maartens

$298-308$

Teaching Afrikaans as emancipatory discourse

ORALITEIT VS. GELETTERDHEID / ORALITY VS. LITERACY

Hildegard van Zweel

$311-327$

Some insights that orality-literacy studies can offer language teachers

SPIL PLUS 27 (1995)

Rudolf P. Botha

$1-63$

The World of Language: 3 Its capacities stratum 